\title{
La fiebre del ámbar en Chiapas. La minería en una región agraria
}

\section{Amber Rush in Chiapas. Mining in an Agrarian Region}

\author{
Sonia Toledo Tello \\ Instituto de Estudios Indígenas, \\ Universidad Autónoma de Chiapas
}

\begin{abstract}
Resumen: En las últimas décadas, el ámbar chiapaneco fue ganando espacios en los mercados regional, nacional e internacional. Pero en 2012 su demanda aumentó significativamente, generándose una sobreexplotación de las minas. El auge duró hasta 2015, aunque las repercusiones socioambientales en el principal sitio de extracción, Simojovel de Allende, han sido notorias. En este trabajo se analizan las condiciones socioeconómicas que permitieron el apogeo del ámbar, así como el impacto que este suceso ha tenido en la dinámica social de la región de estudio, sobre todo entre los jóvenes, mayoritariamente de familias campesinas. El estudio considera las dimensiones temporal y espacial con el fin de analizar los procesos sociales de la región, entendida ésta como una configuración histórica producto de relaciones sociales de poder que trascienden sus límites físicos. Asimismo, la juventud se concibe como una categoría construida en procesos sociohistóricos particulares y no como un estado esencial.
\end{abstract}

Palabras Clave: Simojovel, globalización, ámbar, jóvenes, lo relacional y el poder.

ABSTRACT: In the last few decades, amber from Chiapas gained an important place in regional, national and international markets, but in 2012 the demand increased significantly, generating over-exploitation of the mines. The boom lasted until 2015, however the main social and environmental impacts on the extraction site, Simojovel de Allende, have been notorious. This article analyses the socioeconomic conditions that allowed the heyday of amber, as well as the impact it has had on the social dynamics of the region, especially among young people, mostly from peasant families. The study takes into account temporal and spatial dimensions in order to analyze the social processes in the region, as an historical configuration product of social and power relations that transcend the physical limits. Furthermore, youth is conceived as a category constructed in particular socio-historical processes and not as an essential condition.

KEYwoRDs: Simojovel, globalization, amber, youth, relations and power.

RECEPCIÓN: 12 de octubre de 2016.

ACEPTACIÓN: 30 de enero de 2017.

DOI: 10.19130/iifl.ecm.2018.51.865

\section{Introducción}

Al finalizar el siglo xx, tras dos décadas de violentas disputas agrarias, ex trabajadores agrícolas y avecindados de los ejidos de Simojovel y de algunos otros mu- 
nicipios lindantes — Huitiupán, Bochil, Jitotol, Pueblo Nuevo Solistahuacán—obtuvieron la mayor parte de las tierras que hasta entonces conformaban las fincas agropecuarias. Irónicamente, luego de este logro, muchos de los hijos o nietos de quienes lucharon por las tierras muestran un profundo desinterés por la agricultura. En cambio, cada vez más se suman a las actividades alrededor de la explotación del ámbar: extracción, talla, elaboración artesanal o comercialización. ${ }^{1}$

El propósito de este trabajo consiste en explorar los cambios socioeconómicos recientes y las formas en que se expresa el capitalismo regido bajo políticas neoliberales, considerando las condiciones sociohistóricas que han configurado la región de estudio. Las preguntas que planteo son ¿por qué la tierra recién conquistada dejó de ser el recurso más valorado y codiciado entre las nuevas generaciones de la población rural de esta región? ¿Cuáles fueron los procesos que permitieron que la explotación del ámbar, un recurso natural milenario en la zona, adquiriera relevancia como actividad económica tan sólo en los últimos años?

Para responder parto de las siguientes ideas: las regiones o lugares son configuraciones históricas que se producen, recrean y transforman en medio de una multiplicidad de relaciones sociales de poder que rebasan sus límites físicos y vinculan a sus habitantes con procesos y agentes sociales de distintas latitudes. Tales configuraciones también guardan relación con los bienes o recursos naturales que son histórica y socialmente valorados, apropiados, disputados y explotados (Santos, 2000; Escobar, 2010). Como sostiene Arturo Escobar, no es lo mismo habitar "en un desierto que en un bosque húmedo" (Escobar, 2010: 57). Las condiciones fisiográficas guardan una estrecha vinculación con la manera en que los lugares son construidos por quienes allí habitan. "Los lugares son co-producciones entre las personas y el ambiente" (Escobar, 2010: 57-58). Desde la perspectiva relacional que aquí adoptamos, otro aspecto fundamental a considerar es, como han mostrado Milton Santos (2000) y David Harvey (1998, 2005, 2007), que el capital y el Estado han jugado un papel protagónico en la producción del espacio. De hecho, "Il]a acumulación de capital siempre ha sido una cuestión profundamente geográfica. Sin las posibilidades inherentes a la expansión geográfica desigual, hace tiempo que el capitalismo habría dejado de funcionar como sistema político y económico" (Harvey, 2007: 38). Esto ha sido así a lo largo de la historia del capitalismo, de modo que en la actualidad no es posible obviar la relación entre lo local y lo global, ya que, de acuerdo con William Robinson:

Cada individuo, cada nación y cada región están siendo incorporados a los procesos trasnacionales que han socavado las autonomías y provincialismos anteriores. [Por

\footnotetext{
${ }^{1}$ Este trabajo es resultado de un proyecto de investigación llevado a cabo en el Instituto de Estudios Indígenas (IEI) de la Universidad Autónoma de Chiapas. La información de campo se recopiló en distintos periodos entre 2013 y 2016, con la invaluable colaboración de la Lic. Juana Ma. Ruiz Ortiz, técnica académica del mismo instituto, a quien debo y agradezco la traducción de varias entrevistas del tzotzil al español.
} 
ello es] imposible abordar temas locales -si no es que incluso cualquier asunto de importancia social, política o intelectual- al margen del contexto global (Robinson, 2015: 17).

Por otra parte, en vista de que son los jóvenes de la región en la cual se ubica Simojovel los que principalmente se han volcado en torno a las actividades relacionadas con la explotación del ámbar, es pertinente plantear a qué nos referimos cuando hablamos de juventud. De acuerdo con Margulis y Urresti (s/f), dicha noción suele entenderse, a primera vista, como una simple cuestión de edad, y en este sentido colocarse en el terreno del cuerpo y la naturaleza. No obstante, si tomamos en cuenta la amplia heterogeneidad que las sociedades presentan en el plano económico, social y cultural podemos apreciar que existen distintas maneras de ser joven. Por ello, aquí la juventud se entiende como una categoría construida en procesos sociales e históricos específicos y no como un estado biológico “esencial” (Maidana, Colangelo y Tamagno, 2013). Así pues, para el estudio de la región, vista como un lugar, y de los jóvenes o agentes sociales en general, me guío por una perspectiva relacional y constructivista (Bachelard, 1988; Bourdieu y Wacquant, 1995).

\section{Configuraciones históricas de Simojovel y la región en la que se ubica}

Hoy en día, el municipio de Simojovel de Allende (Mapa 1) es conocido como tierra del "ámbar", aunque muchas familias siguen teniendo la agricultura como una de sus principales actividades económicas y, como veremos, durante mucho tiempo fue reconocido como productor de tabaco, café y ganado. Pero, por otra parte, en efecto, este municipio y varios más a su alrededor, "desde Tapilula hasta Yajalón y del Bosque hasta Pantelhó” (Ytuarte, 2014: 78), constituyen una de las pocas regiones de México que cuenta con yacimientos de ámbar; dos zonas más se localizan en Chiapas también, Ixtapa-Soyaló y Totolapa. El ámbar es una resina vegetal fosilizada y su antigüiedad en esta entidad mexicana se ha calculado de entre 22.5 y 26 millones de años (Figura1) (Lowe, 2005: 17). Asimismo, existen minas en algunas otras partes del mundo como "las costas del mar Báltico, República Dominicana, China, Rumania, Burma, Sicilia, Canadá, Alaska, Líbano, Siberia y Estados Unidos" (Lee, 2004; Lowe, 2005: 17).

Gracias a cronistas, historiadores, arqueólogos, geógrafos y viajeros, se sabe acerca de los yacimientos de esta resina fósil, de su uso en distintos tipos de ornamentos y de los símbolos asociados a ella desde tiempos remotos en Asia y Europa, así como durante las épocas prehispánica y colonial en Mesoamérica. De ello hacen un recuento los dos autores antes citados y, más recientemente, Claudia Ytuarte (2014); los tres destacan que en distintas épocas han existido artesanos especializados en la elaboración de ornamentos, amuletos, rosarios y una gran variedad de artículos decorativos. 


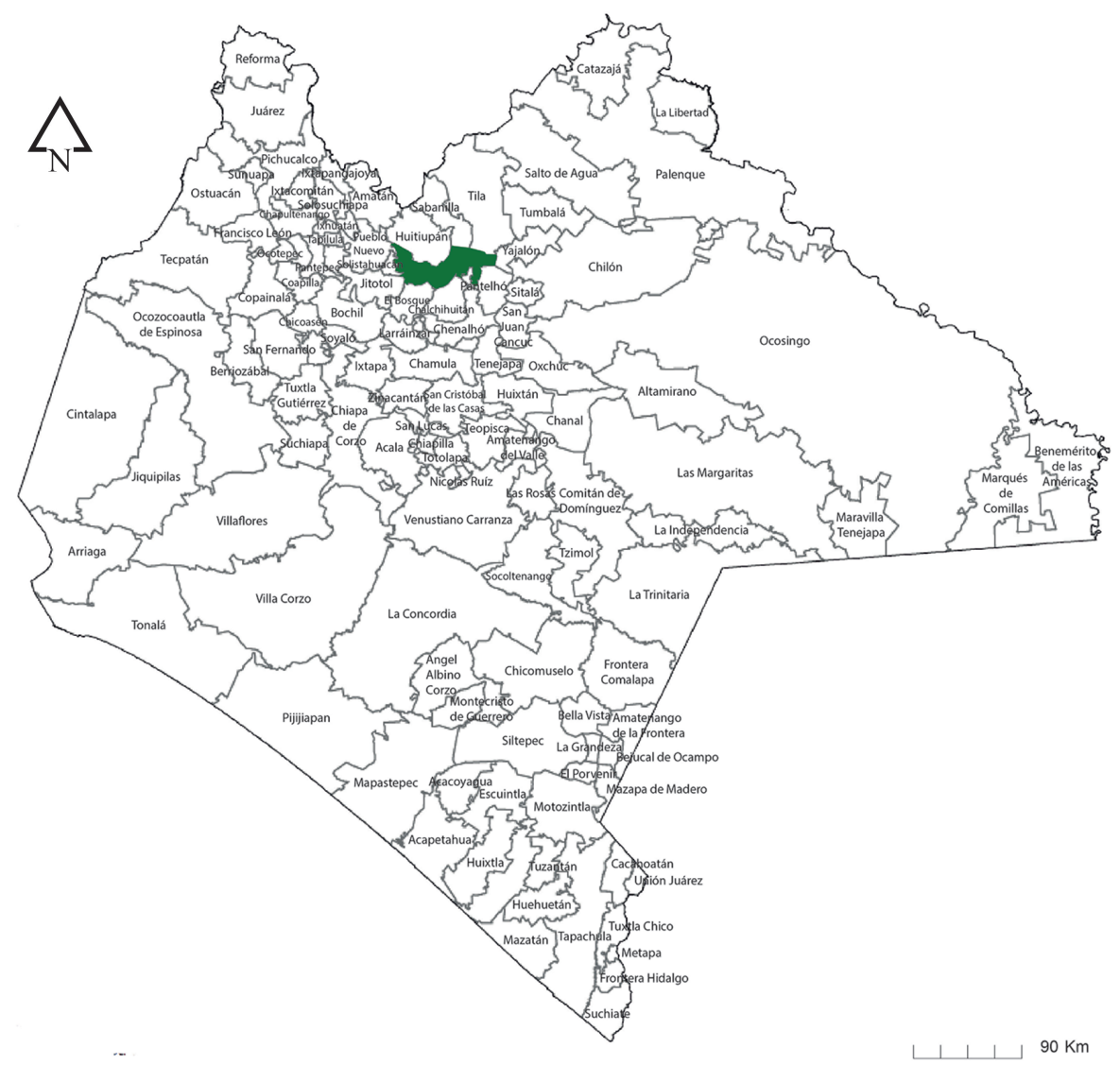

Mapa 1. Ubicación del municipio de Simojovel, en el norte de Chiapas. Fuente: INEGI. Dibujo de Natasha S. Báez.

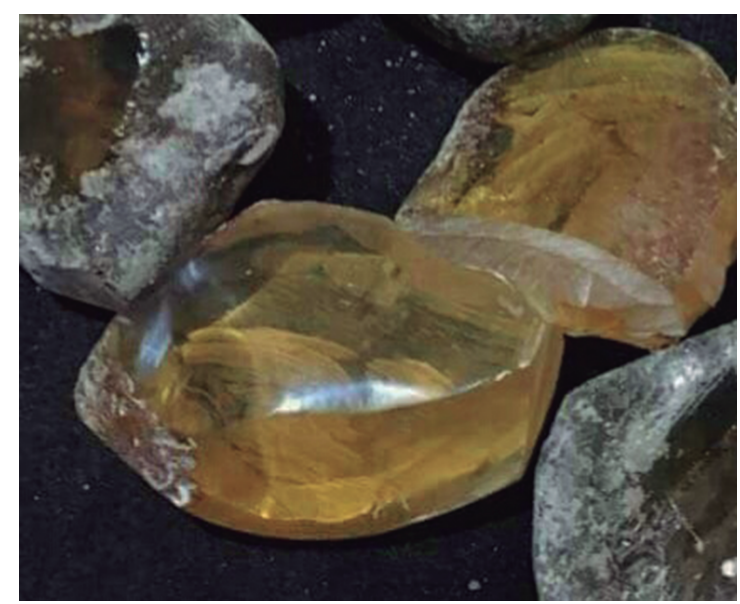

Figura 1. Ámbar de Simojovel. Fotografía de Lili García Mayorga. 
Para el caso de Mesoamérica, los cronistas coloniales en general hicieron referencia a la gema como una de las "piedras" preciosas que se hallaban en estas tierras y subrayaron las propiedades curativas que se le atribuían. No obstante, sabemos que, a su llegada, los peninsulares buscaban oro y plata, metales escasos en el territorio que hoy es Chiapas. De este modo, los recursos que se explotaron durante la Colonia fueron la tierra y la mano de obra india. Productos como maíz, cacao, algodón y tabaco, junto con aquellos que se introdujeron, ganadería - bovina, caballar y ovina-, caña de azúcar, trigo y añil, fueron la base de la economía.

Así, Chiapas, y específicamente la región donde se ubica Simojovel, fue integrada a la economía mundial desde el período colonial como una sociedad agraria. Además, existen breves referencias acerca de que en el siglo xvII el ámbar y el tabaco de Simojovel y la zarzaparrilla de Huitiupán se producían, aunque a escala baja, para el mercado. El primero destinado al mercado interno y los otros dos productos para exportar "preferentemente de contrabando" a España (Viqueira, 1997: 36-37). Los habitantes de esta región, hablantes de tzotzil (una lengua mayanse), fueron reagrupados en pueblos de indios tributarios de la Corona española, que pertenecían a la Guardianía de Huitiupán. ${ }^{2}$

En el siglo XIx, ya en el período independiente, estos pueblos de indios vivieron una profunda crisis demográfica y los ladinos provenientes de San Cristóbal de Las Casas y de Comitán adquirieron las tierras de la diezmada población, así como terrenos baldíos donde establecieron numerosas fincas de tabaco, maíz, frijol y ganado. ${ }^{3}$ Con la implantación del cultivo de café por parte de muchas de estas empresas agropecuarias, la zona se insertó en el mercado internacional desde finales del siglo xIx, como un pequeño enclave agroexportador. De manera que la economía siguió girando en torno a la explotación de la tierra y de la fuerza de trabajo local, solo que la mayor parte de la población indígena pasó de la condición de tributaria de la Corona española a la de servidumbre agraria en las fincas (Toledo, 2002, 2012).

En cuanto al ámbar, durante el siglo xIX algunos geógrafos y viajeros dieron cuenta de su existencia, pero su explotación era escasa; Lee (2004) y Lowe (2005: 17) también hacen referencia a tales trabajos.

${ }^{2}$ La Guardianía de Huitiupán quedó integrada en 1589 bajo la administración de los frailes franciscanos. Comprendía, además de Simojovel, los pueblos de indios de San Andrés Huitiupán, Santa Catarina Huitiupán, San Pedro Huitiupán, Plátanos y Moyos. La cabecera fue el pueblo de Asunción Huitiupán, lugar en donde se edificó el convento franciscano (Viqueira, 1997: 96, 97).

${ }^{3}$ Las propiedades privadas rurales en la zona eran conocidas como fincas, aunque agrupaban tanto a los ranchos como a las haciendas, dos unidades de producción distintas. Los ranchos producen a pequeña escala, su lógica no es totalmente empresarial y la producción se basa en el trabajo directo del propietario y de su familia, aunque también se contrate mano de obra (Bartra, 1979: 165). Mientras que las haciendas operan en una situación de escasez debido a que el capital es de una persona, y raramente es puesto en mancomunidad con los recursos de capital de otras partes. Su funcionamiento se sustenta en el empleo intensivo de la fuerza de trabajo. En este sistema, la forma típica de propiedad es la familiar, la movilidad de la riqueza se da mediante lazos de parentesco y amistad personal, y no es delegada a una corporación. El sistema de hacienda busca, además de las ganancias por el capital invertido, fondos para la reproducción familiar y las aspiraciones de poder y prestigio (Wolf y Mitz, 1975). 
Entre 1930 y 1950, con el reparto agrario, se redujo en general el tamaño de las fincas (muchas veces de manera simulada), se formaron numerosas pequeñas propiedades y diez ejidos en Simojovel. ${ }^{4}$ Es decir, hubo cambios, pero la región seguía siendo eminentemente agraria con el predominio de la propiedad privada de la tierra, ${ }^{5}$ lo que se tradujo en una forma específica de ocupación del espacio físico, derivada de las formas de tenencia de la tierra y de las relaciones sociales que se construyeron en torno a éstas.

En cuanto a la explotación del ámbar en el siglo xx, Frans Blom anotó que en un viaje realizado a Simojovel en 1922:

[...] los indios recogen el ámbar en las montañas cercanas y lo traen al pueblo a vender. Los artesanos locales usan este ámbar para hacer cruces chicas, manos, lágrimas y otras formas que utilizan en la región como amuletos para proteger a los infantes contra "el mal de ojo" (Blom, 2004: 68).

A mediados del siglo xx, Moisés de la Peña comentó acerca de la gema:

En Simojobel [sic] se habla de distintas localizaciones, pero nada hay de cierto, como no sea un derrumbadero que se halla en la ribera derecha del río Catarina $[\ldots]$ y en estos derrumbes repetidos en los períodos de lluvia de todos los años, los campesinos encuentran fragmentos de ámbar de gran pureza (algunos con moscas y otros cuerpos extraños en el interior). En Simojobel hay artistas que compran el ámbar y elaboran rosarios, collares, cruces, boquillas, arracadas, prendedores y otros objetos con incrustaciones de oro y de plata, que son muy solicitados [...] No parece haber propiamente una veta o manto (De la Peña, 1951 (IV): 1221).

Por su parte, Carlos Navarrete y Thomas Lee escribieron sobre su visita a Simojovel en 1968:

[Por] la fama popular de "las minas" y los "ambareros de Simojovel" podría suponerse que una parte importante de los habitantes de este municipio "vive de la explotación de esta resina solidificada [...]". La realidad es totalmente opuesta y decepcionante en cuanto al número de individuos que en la actualidad viven o complementan así su economía.

[...] No llegan a diez los hombres que se dedican a extraer el ámbar y de éstos solamente tres lo hacen con cierta regularidad [...] (Navarrete y Lee, 2004: 78 y 80).

\footnotetext{
${ }^{4}$ El ejido es una forma de propiedad social y hasta 1992 fue inalienable.

5 Todavía en 1970, en Simojovel existían 185 haciendas y ranchos que concentraban el 45.3\% de la población total de municipio (7 112 de un total de 15 683), 10 ejidos con 24\% (9 796) de los habitantes, la cabecera municipal con otro $24 \%$ y el resto vivía en pequeñas rancherías. En Huitiupán, por ejemplo, se registraron 73 ranchos y seis haciendas que en conjunto congregaban $34.5 \%$ de la población del municipio (3 785 de un total de10 940), 16 ejidos con 53.8\% (5887) de la población y el resto se asentaba en la cabecera municipal (IX Censo General de Población, 1970).
} 
En este sentido, Andrés Gómez Hernández, ejidatario de Lázaro Cárdenas, Simojovel, comentó:

Antes, la mayoría trabajábamos en puras milpas, cuando hacíamos la limpia con azadón a veces salía el ámbar... la gente no le hacía caso. Nosotros no sabíamos que tenía precio, era como cualquier piedra, ahí lo dejábamos tirado o se usaba para curación en algunas personas o para proteger a los bebés del mal de ojo [...] (Entrevista, Simojovel de Allende, julio de 2015).

De igual forma, Gilberto Trejo, expropietario del rancho Los Arrayanes y actualmente representante de la agrupación Artesanos del Ámbar A.C., platicó que, cuando vivía en su propiedad, con frecuencia encontraba ámbar, pero como "no tenía precio" no lo recogía, lo tiraba como "cualquier piedra”. Agregó que de haber guardado alguna de las grandes piezas halladas, hoy tal vez se hubiera hecho rico. "Recientemente —añadió- un campesino vendió un buen trozo en dos millones de pesos" (Entrevista, Simojovel de Allende, julio de 2016).

Desde mediados del siglo xix hasta la década de 1970, las minas se encontraban fundamentalmente en los terrenos de las fincas agropecuarias; sin embargo, el ámbar no se había constituido en un recurso con valor en el mercado. La mayor parte de la población trabajaba supeditada a los requerimientos de las fincas como peones acasillados, arrendatarios o baldíos, jornaleros temporales, arrieros, vaqueros y sirvientes de casa o trabajadores eventuales con distintos oficios - carpinteros, tejeros, albañiles, costureras-. Con la formación de los ejidos, sus beneficiarios reprodujeron a pequeña escala los cultivos que se practicaban en las fincas. Asimismo, entablaron relaciones laborales, comerciales y de endeudamiento con los finqueros. Habitantes de los ejidos formaban parte de los jornaleros temporales de las fincas y dependían de los canales de comercialización controlados por los finqueros para vender sus productos agrícolas. De igual forma, varios campesinos de los ejidos siguieron acudiendo a los propietarios de los ranchos solicitando préstamos para la producción y para solventar gastos rituales y de salud, en tanto que una parte importante de la población continuó como trabajadora permanente de las fincas, como lo muestran los datos del censo de 1970.

\section{Transformaciones del lugar al finalizar el siglo $\mathrm{xx}$}

Precisamente en los años setenta, a raíz de una serie de procesos económicos, culturales y políticos nacionales e internacionales, se construyó un masivo y violento movimiento agrario que puso fin a las fincas y generó la campesinización del municipio de Simojovel (Mapa 2), así como de varios más de la región: Huitiupán, Bochil, Jitotol, El Bosque y Pueblo Nuevo Solistahuacán. En efecto, en ese entonces se produjo una importante caída de los precios del café y al mismo tiempo un aumento en la demanda de productos derivados del ganado vacuno 
en el mercado internacional, lo que propició la sustitución de tierras dedicadas a la agricultura por pastizales, para dar paso a un proceso de ganaderización extensiva. En el mismo periodo se llevaron a cabo los primeros trabajos para la construcción de la presa hidroeléctrica Itzantún. Esta obra afectaría 205 predios que abarcaban 10,912 hectáreas; $46 \%$ de las cuales eran territorio del municipio de Huitiupán y $42 \%$ de Simojovel, así como pequeñas fracciones de algunos municipios más. La mayor parte de estos terrenos pertenecían a las fincas (Toledo, 2012: 131).

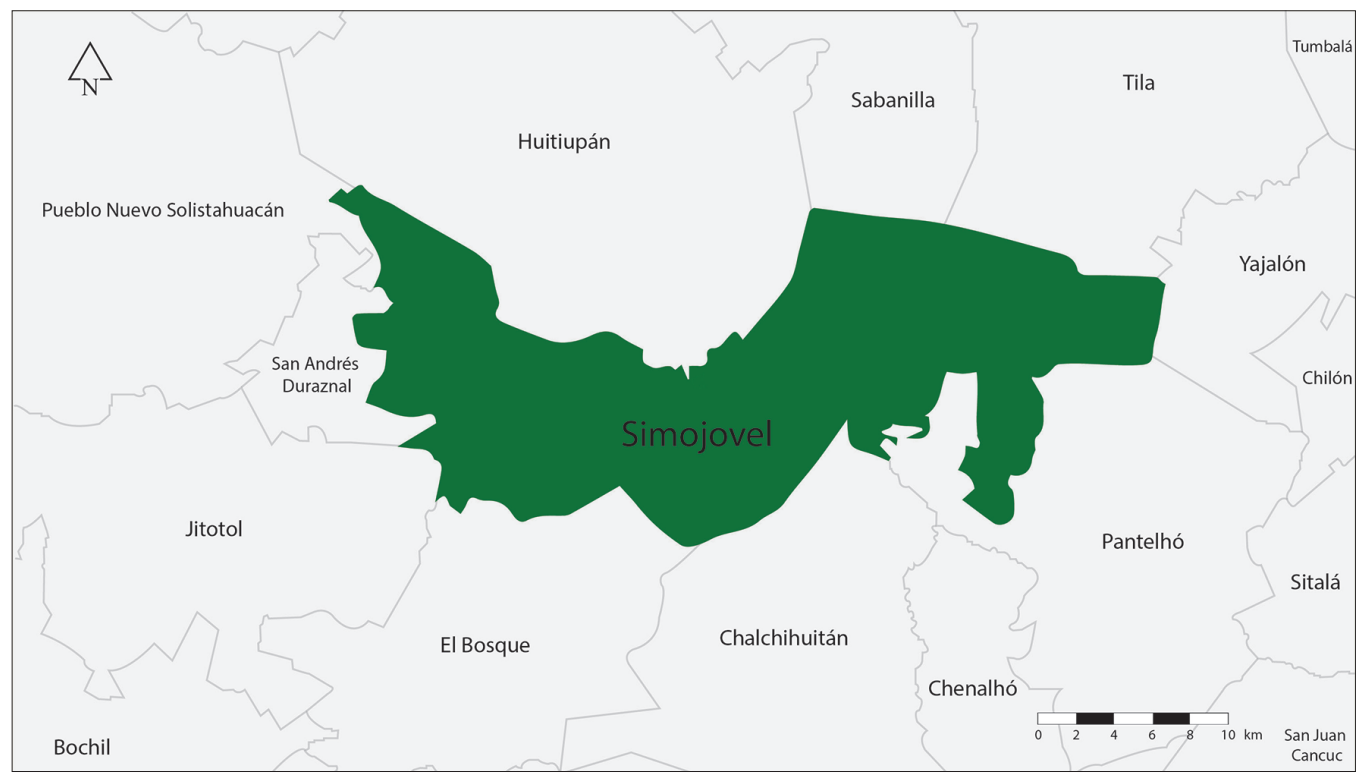

Mapa 2. Municipio de Simojovel. Fuente: INEGI. Dibujo: Natasha S. Báez.

Como resultado de la ganaderización y la venta de las tierras privadas para la construcción de la presa, un gran número de familias de trabajadores permanentes fue expulsado de las fincas. Este hecho también significó el cierre de la principal fuente de empleo para jornaleros temporales, campesinos arrendatarios, vaqueros, albañiles y carpinteros de la zona. Aunado a lo anterior, el aumento de la población en edad de trabajar de los ejidos de la zona provocó una fuerte presión sobre la tierra; sin embargo, bajo el argumento de que sólo había pequeñas propiedades, las solicitudes de ampliación fueron negadas.

Así, sin ninguna otra opción de trabajo y residencia, los trabajadores expulsados de las fincas y los campesinos sin tierra de los ejidos se organizaron en torno a la lucha agraria durante la segunda mitad de la década de 1970, apoyados por la labor ideológica y política de la diócesis de San Cristóbal y de las organizaciones campesinas independientes: Organización Campesina Emiliano Zapata 
(OCEZ), Línea Proletaria y, principalmente, la Central Independiente de Obreros Agrícolas y Campesinos (CIOAC).

Para 1985 casi todas las fincas habían sido tomadas por los ex trabajadores y campesinos sin tierra, y la construcción de la presa fue suspendida. Tras 20 años de enfrentamientos, persecuciones, encarcelamientos y asesinatos, la mayor parte de los participantes en el movimiento logró la regularización de casi todos los predios, incluso los contemplados para el proyecto hidroeléctrico Itzantún. Varios de los nuevos ejidatarios tuvieron acceso a programas de gobierno, como la escuela y los apoyos para la educación de los hijos, electrificación, drenaje, pavimentación, entre otros (Toledo, 2012).

En este apretado resumen histórico observamos que las actividades económicas y las relaciones sociales, así como las principales tensiones y disputas giraron alrededor de la tierra y la producción agropecuaria a lo largo de varios siglos.

En cuanto al ámbar se refiere, durante mucho tiempo sus usos habían sido ornamentales y mágico-religiosos, incluso llegó a ser uno de los productos que se tributaban en los períodos prehispánico y colonial, pero la resina fósil no llegó a adquirir una importancia tal que demandara una explotación mayor. ¿Qué fue entonces lo que generó la sobreexplotación de la gema en años recientes?

Considerando que los procesos locales guardan estrecha conexión con dinámicas más amplias, podemos entender que a pesar de que los yacimientos de ámbar en Simojovel son milenarios, su explotación intensiva surgiera en las últimas décadas del siglo xx, en un momento en el cual convergieron diversos procesos regionales, nacionales e internacionales.

Mientras la región de Simojovel vivía cambios significativos a raíz de la toma de las tierras de las fincas y la campesinización de buena parte de los ex trabajadores, la política agraria en México, que había sido uno de los pilares para la consolidación del Estado posrevolucionario, se encontraba en una fase de grandes transformaciones. En los años ochenta, con la adopción del modelo neoliberal por parte del gobierno mexicano, ${ }^{6}$ instituciones y políticas que habían asistido a los productores campesinos fueron desmanteladas para canalizar los apoyos productivos exclusivamente a la agricultura capitalista. Desde entonces la economía campesina entró en una crisis severa.

Asimismo, si bien es cierto que el movimiento agrario fue regional y masivo, no todos los trabajadores de las fincas y solicitantes de tierras de los ejidos optaron por participar en la lucha por la tierra, las razones fueron diversas. Algunos decidieron seguir al patrón a la cabecera municipal y trabajar como sirvientes en las casas o como empleados en los establecimientos comerciales de éstos. Tam-

\footnotetext{
${ }^{6}$ De acuerdo con David Harvey, "[e]l neoliberalismo es, ante todo, una teoría de prácticas políticoeconómicas que afirma que la mejor manera de promover el bienestar del ser humano consiste en no restringir el libre desarrollo de las capacidades y libertades empresariales del individuo dentro de un marco institucional caracterizado por derechos de propiedad privada fuertes, mercados libres y libertad de comercio. El papel del Estado es crear y preservar el marco institucional apropiado para el desarrollo de estas prácticas" (Harvey, 2007: 6).
} 
bién hubo quienes compraron pequeños predios o solicitaron su ingreso a ejidos de la región ya constituidos. Parte de las familias que decidieron trasladarse a la cabecera municipal de Simojovel encontraron en la extracción y talla del ámbar una de las escasas alternativas económicas. ${ }^{7}$

Los integrantes del grupo de artesanos Choj-Choj, formado hace más de dos décadas, dan cuenta de este proceso. Domingo Sánchez, representante del grupo, es originario del rancho El Pocito, en el que también nacieron su padre y su madre. Al finalizar la década de 1970, cuando tenía 11 años de edad, su padre decidió abandonar esta propiedad porque "el patrón, don Manuel Morales, pagaba muy poco", y con lo que ganaban les era imposible satisfacer sus necesidades. Así llegaron a vivir a la cabecera municipal de Simojovel y, después de algunos años de arrendar terrenos y trabajar como jornaleros con diferentes rancheros, Domingo empezó a excavar minas de ámbar, alentado por Benito, su hermano mayor, quien ya era tallador de la resina. Durante cinco años fue minero, rentaba minas en el rancho El Pocito. Después, hace 25 años, decidió meterse a la producción artesanal, a "darle forma al ámbar". Cuando empezaron, Domingo, su hermano y sus seis amigos eran de los pocos artesanos que había en Simojovel.

Durante la plática con Domingo, intervino otro de los integrantes del grupo, Roberto Díaz, diciendo que él y su familia también salieron de un rancho (Chamaluk'um) porque la gente empezó a invadir las tierras y ellos no querían problemas. Él "era muy chamaco, tenía como 10 años, pero el patrón era bueno porque permitía que los acasillados sembraran sus milpas y sus verduras". ${ }^{8}$ Ya cuando vivía en Simojovel aprendió a trabajar el ámbar. Afirma que es difícil hacer las formas, "hay que hacerlo con mucho cariño para que salga bien" (Entrevistas, Simojovel de Allende, julio de 2015).

Hasta antes de 1980 eran tan sólo cuatro las familias que adquirían el ámbar en la cabecera municipal de Simojovel con los escasos mineros que existían. Una mujer en especial, integrante de las familias poderosas del municipio, dedicadas a la actividad agrocomercial, se destacó por el papel que jugó en el incipiente sector ambarero en el último tercio del siglo xx. Ella acaparaba el ámbar siguiendo el viejo mecanismo de préstamos por adelantado utilizado por los rancheros de la zona con los trabajadores agrícolas. Contaba con una gran cantidad de piezas de calidad, razón por la cual atrajo a coleccionistas de Estados Unidos, Canadá y Europa, específicamente de "Alemania, Italia, Suiza y Francia" (Ytuarte, 2014: 69-71). En una conversación sostenida en 1998 con su esposo, el ahora finado Esteban Zúñiga, éste comentó que mandaban ámbar a Indonesia para que le hicieran "finos engarces en plata". Al fallecer su mujer, su hijo menor y su nieta retomaron el negocio y se establecieron en San Cristóbal de Las Casas.

\footnotetext{
${ }^{7}$ Sobre el movimiento agrario y los distintos procesos sociales que se desencadenaron, pueden consultarse Salazar, 1988; Pérez, 1989; Harvey, 2000; Toledo, 2002, 2012.

${ }^{8}$ Muchos trabajadores de las fincas entendían las relaciones sociales patrón-peón en términos de bondad o maldad. Esta visión era resultado y, en buena medida, reproductora de los complejos mecanismos de dominación y explotación en las fincas (Toledo, 2002).
} 
En los años noventa, los efectos de la prolongada crisis de la economía campesina - sin créditos, sin insumos a precios accesibles, dependientes de los intermediarios para la comercialización, padeciendo además la creciente importación de productos como el maíz a bajos costos, más las recurrentes caídas del precio internacional del café- poco a poco empujaron a campesinos con tierra a incorporarse a la explotación del ámbar para completar su precaria economía. Esto, gracias a que por aquellos años había crecido de manera significativa la demanda de la gema.

Claudia Ytuarte (2014) plantea que en esta década de los noventa fueron varios los acontecimientos que intervinieron en el aumento de la demanda de productos como el ámbar en el mercado regional, nacional e internacional y se generó un gran interés por los fósiles (Figura 2), debido a la difusión de descubrimientos científicos que sostenían que el ADN podía ser preservado. La corporación Ambergene, anota Thomas Lee, "fue fundada para explorar el potencial científico y comercial del ADN contenido en los insectos en el ámbar, del que esperan producir medicinas, enzimas industriales y pesticidas naturales" (Lee, 2004: 42). A partir de esta noticia, novelas y películas de ciencia ficción (como Jurassic Park) contribuyeron a crear una amplia atracción por las piezas fosilizadas. En esos años, el ámbar mexicano logró un lugar en el Museo Americano de Historia Natural y fue exhibido en distintas ciudades estadounidenses. Asimismo, la autora destaca que otro elemento importante fue la afluencia a Chiapas del llamado turismo "revolucionario" que, atraído por el movimiento zapatista, aprovechaba para conocer las "bellezas" del estado (Ytuarte, 2014: 73, 74).

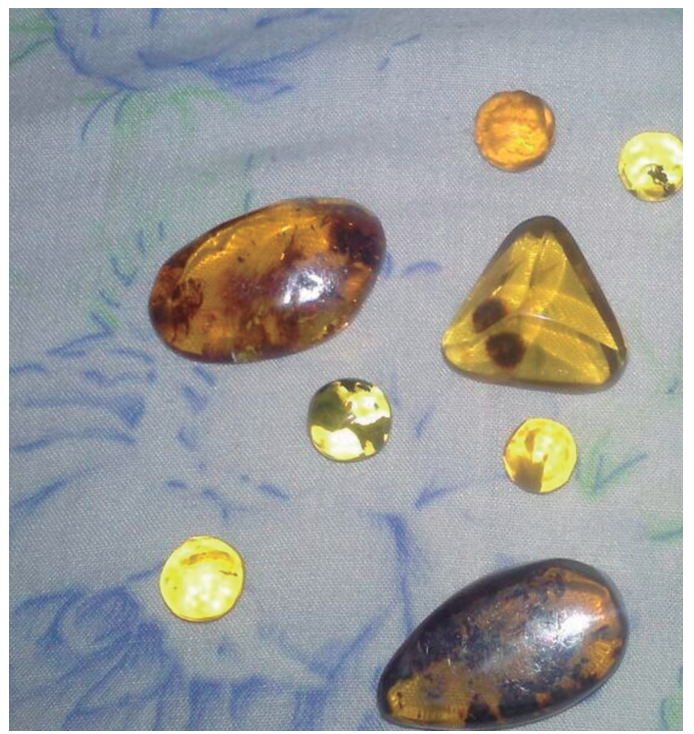

Figura 2. Piezas de ámbar con insectos, hojas y musgo. Fotografía de Lili García Mayorga. 
A Simojovel empezó a llegar un mayor número de compradores de la gema, de origen norteamericano, alemán, canadiense y japonés, además de los nacionales, que extendían así las redes de mercado de esta mercancía. Entre finales del siglo $\mathrm{xx}$ y principios del actual, proliferaron los puestos ambulantes y las tiendas establecidas de la resina fosilizada en distintos puntos de la entidad y del país, incluso se crearon los museos del ámbar en San Cristóbal de Las Casas y en la cabecera municipal de Simojovel.

Algunos mineros relatan que el ámbar que no compraban los principales acaparadores lo adquirían los comerciantes de San Cristóbal de Las Casas a precios sumamente bajos, los extranjeros que llegaban a comprar al mayoreo (por lo regular buscaban ámbar rojo (Figura 3) ya que es el más escaso y, en ese entonces, mejor cotizado), y nacionales y extranjeros conocidos como "jipitecas", quienes hasta la fecha lo trabajan artesanalmente y lo venden en los principales centros turísticos de México (Toledo, 2002: 54, 55). Al igual que ahora, era común que mujeres y niños ofrecieran piezas en las calles y en la plaza central de la cabecera municipal, sobre todo a las personas que reconocen como foráneas y a los mismos comerciantes establecidos de Simojovel.

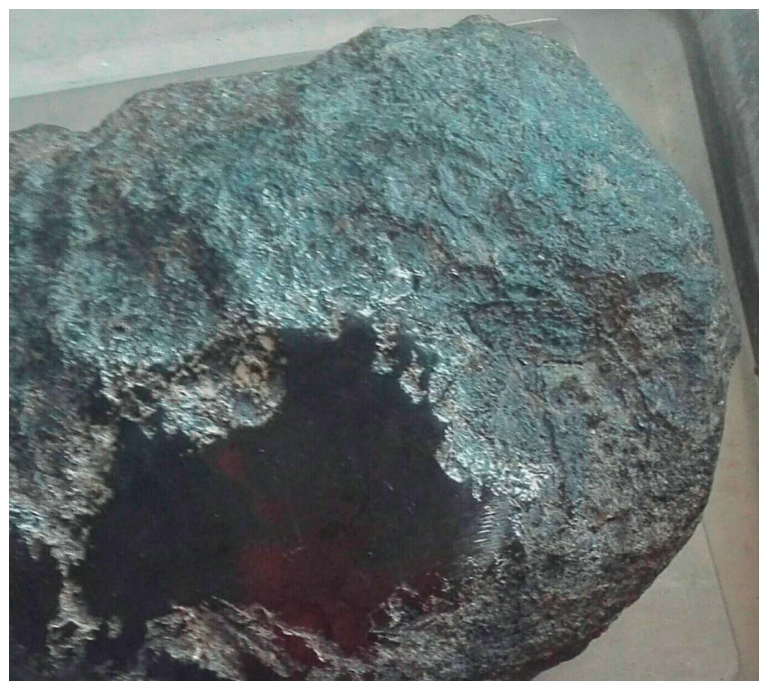

Figura 3. Ámbar rojo sin pulir. Fotografía de Lili García Mayorga.

En 1998 se registraron cerca de 450 mineros agremiados en la Organización Campesina Obrero Popular del Estado del Chiapas (OCOPECH), filial del Partido del Trabajo (PT). ${ }^{9}$ Aunque el número de personas dedicadas a la minería pudo ser

\footnotetext{
${ }^{9}$ Este partido ocupó la presidencia municipal de Simojovel de 1995 a 1997. Por su parte, la agrupación de mineros perteneciente a la OCOPECH se desintegró en 1999, a raíz de lo que muchos de sus integrantes llamaron un "auto-robo" de piezas de ámbar que exhibían y vendían en su local.
} 
mayor, en las décadas de 1990 y 2000 los cultivos del café y del maíz seguían siendo las principales actividades productivas de la población rural. Muchas de las comunidades formadas a fines del siglo $\mathrm{xx}$, al conquistar las tierras de las fincas, no enfrentaban la presión sobre las parcelas familiares, la mayoría contaba con seis o nueve hectáreas; cantidad suficiente comparada con las parcelas de un cuarto de hectárea o menos de algunas comunidades de los Altos. En contraste, algunos habitantes, sobre todo de los ejidos formados entre 1930 y 1950, con escasez de tierra y sin otras alternativas económicas, empezaban a migrar hacia el norte del país y los Estados Unidos.

Al mismo tiempo, la minería y las artesanías de ámbar seguían incorporando a más personas. Así, en 2007, ligado al entonces recién inaugurado Museo Comunitario del Ámbar de Simojovel, ${ }^{10}$ se inició un proyecto turístico en el ejido Pabuchil Los Cocos, bajo la coordinación de Patricia Díaz Ruiz. En 2011-2012 la autoridad municipal retomó este trabajo para impulsar el proyecto turístico "Sendero del ámbar Pauchil Los Cocos". Con este proyecto se realizaron obras para hacer accesibles los recorridos al turismo. Se arregló un sendero de 1500 metros que conduce a las minas en Pauchil Los Cocos. Sin embargo, la población le impidió a la coordinadora seguir trabajando allí. Los ejidatarios, propietarios de minas y artesanos arguyeron que el proyecto era de ellos, independiente de la autoridad municipal (Entrevista, ex coordinadora de Turismo del Ayuntamiento, licenciada Patricia Díaz Ruiz, cabecera municipal de Simojovel, junio de 2014). ${ }^{11}$

\section{La irrupción oriental y la fiebre del ámbar}

En 2012 inició un proceso sin precedentes, hombres y mujeres, sobre todo jóvenes, empezaron a involucrarse masivamente en actividades relacionadas con el ciclo de explotación del ámbar, incluso muchos provienen de municipios aledaños como Huitiupán, El Bosque, Jitotol, Pueblo Nuevo Solistahuacán, San Andrés Duraznal y Bochil. La nutrida participación de jóvenes de la zona en esta actividad obedece al hecho de que a mediados del año 2012, además de los compradores de las distintas nacionalidades ya mencionadas, llegaron clientes de origen chino, quienes aceleraron la incorporación de la población regional a la explotación de la resina fosilizada.

\footnotetext{
${ }^{10}$ Mineros y artesanos de Simojovel aportan piezas y cooperaciones para el funcionamiento del museo.

${ }^{11}$ La licenciada Díaz Ruiz fue invitada a coordinar el proyecto por su formación y conocimientos sobre la zona y el ámbar. Nació en la cabecera municipal simojovelense, de padres originarios de un rancho que se establecieron en la cabecera como parte de esa oleada de familias que llegó del área rural a raíz de los conflictos agrarios de los años setenta del siglo xx. Creció tallando ámbar, colaborando así con la economía familiar. Es de las pocas mujeres jóvenes, provenientes de las familias talladoras de ámbar, que lograron terminar una carrera exitosamente. Es licenciada en turismo por la Universidad Intercultural de Chiapas, con sede en San Cristóbal de Las Casas.
} 
Estos nuevos compradores llegaron buscando esferas de ámbar amarillo totalmente limpio y transparente, sin excluir piezas especiales por su color, con insectos o algún residuo vegetal, y elevaron los precios (Figura 3). Antes de su arribo, el gramo del ámbar amarillo de primera se pagaba a $\$ 70.00$ o $\$ 75.00$ pesos. Desde mediados de 2012 los chinos empezaron a comprar el gramo de primera (totalmente limpio) a $\$ 285.00$ y $\$ 250.00$, el de segunda a $\$ 150.00$ y el de tercera a $\$ 100.00$, montos sin precedentes en la zona.

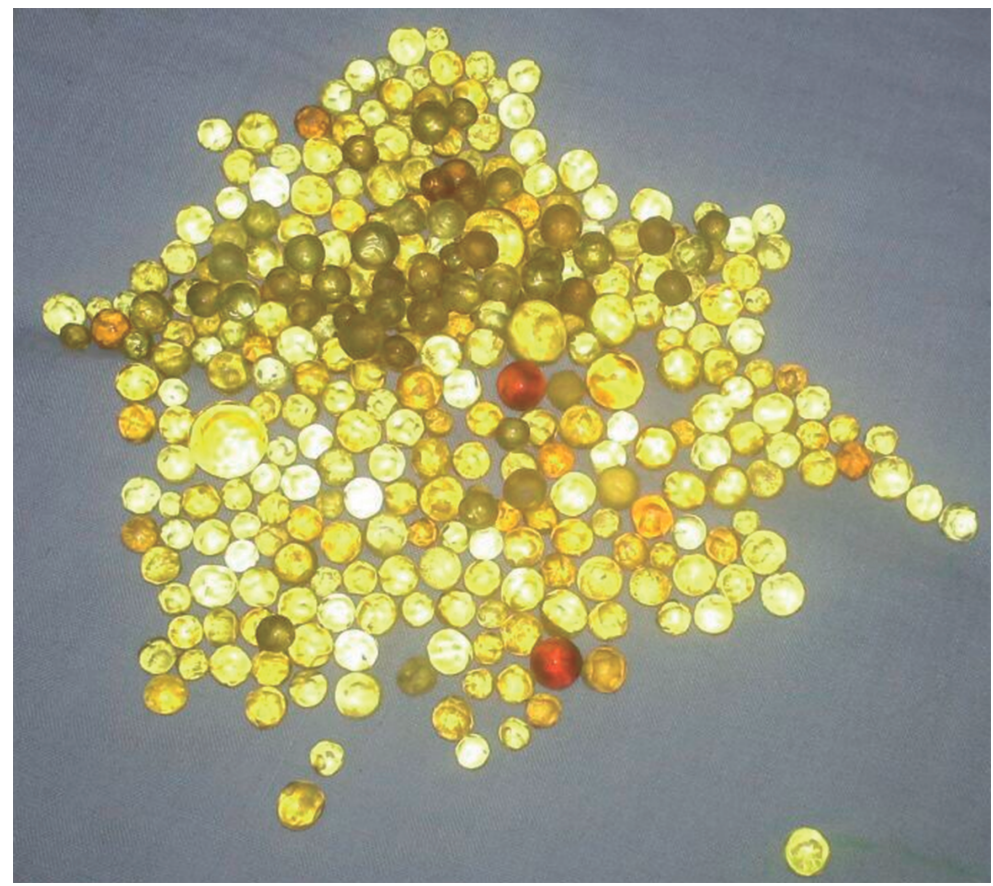

Figura 4. Esferas de ámbar de distintos colores, tamaños y calidades. Fotografía de Lili García Mayorga.

Con estos precios, los compradores chinos estimularon la apertura de un gran número de minas en distintas localidades del municipio de Simojovel, poniendo rápidamente a su disposición considerables cantidades de ámbar de la mejor calidad. De este modo aumentó el número de yacimientos en explotación en los lugares en donde ya se extraía ámbar, como Pabuchil Los Cocos o Los Pocitos, y varios ejidos más abrieron yacimientos para su explotación: Carmen Las Limas, Monte Cristo, Sólo Dios, Lázaro Cárdenas, Guadalupe Victoria, La Pimienta, La Ceiba, La Ceibita, El Chapayal, entre otros, al igual que en algunos más de los municipios de Huitiupán, San Andrés Duraznal y Pueblo Nuevo Solistahuacán.

La llegada de los compradores chinos a Simojovel se inscribe en el marco de las transformaciones socioeconómicas que también se han registrado en las 
últimas décadas en aquel país. En efecto, al tiempo que la región de Simojovel vivía el proceso de cambios ya referido, con el fin de las fincas, la campesinización de los ex trabajadores de estas empresas agropecuarias y, como resultado de las políticas neoliberales que el Estado mexicano adoptaba en esos años, la generación de una crisis profunda de la agricultura de los pequeños productores, la economía de la República Popular China se abría al mundo, al mercado global.

Después de la muerte de Mao Tse-Tung, en 1976, su sucesor Deng Xiaoping impulsó grandes reformas dirigidas a la modernización de la agricultura, la industria, la ciencia y la tecnología, así como las políticas. Tales medidas, afirma Eugenio Anguiano Rocha, permitieron a la República Popular de China participar de manera creciente en los ámbitos comerciales y financieros mundiales desde la década de 1980 (Anguiano, 2010: 436). Las medidas impulsadas por Xiaoping, permitieron "la liberalización de una economía comunista en un país que integra la quinta parte de la población mundial” (Harvey, 2007 [2005]: 5).

El extraordinario desarrollo económico alcanzado por China no sólo se debe a sus cambios internos, fue posible por las transformaciones que al mismo tiempo se registraban en el mundo capitalista avanzado, afirma Harvey: "El impulso que cobraron las políticas neoliberales en el comercio internacional durante la década de 1980 abrió el mundo entero a las fuerzas transformadoras del mercado y de las finanzas" (Harvey, 2007: 131-132).

Lo que hay que destacar aquí, como sostiene William I. Robinson, es que actualmente "ningún país o región" está "fuera del capitalismo mundial". Con una cita de Richard Freeman, el autor subraya que la incorporación de China, India y la ex Unión Soviética a la economía capitalista global representa uno de los sucesos más relevantes de nuestros tiempos, pues hoy en día buena parte de la humanidad se encuentra bajo la dinámica del capitalismo de mercado (Robinson, 2015 [2008]: 28, 29).

Fue en este contexto mundial, a partir de los años ochenta, que México y China emprendieron procesos de reconversión hacia economías de mercado. Sin embargo, de entonces a la fecha el crecimiento comercial del país asiático ha sido muy superior al mexicano. ${ }^{12}$ A raíz del ingreso de China a la Organización Mundial del Comercio (OMC), ${ }^{13}$ en 2002, México se ha visto afectado, pues las exportaciones chinas a los Estados Unidos lo han desplazado de ese lugar que es su principal mercado.

\footnotetext{
${ }^{12}$ Carlos Morales Troncosa (2012) muestra las enormes diferencias en el crecimiento comercial de ambos países durante 25 años.

${ }^{13}$ La OMC se fundó en 1995. Tiene sus antecedentes en el GATT y en la llamada "Ronda Uruguay", reunión celebrada en 1986, en la que se incorporaron temas de comercio internacional como servicios, agricultura, textiles, y propiedad intelectual (Harvey, 2007; Robinson, 2015). Su función principal es negociar acuerdos que favorezcan el mercado internacional y garanticen condiciones de igualdad para sus integrantes. Sin embargo, habría que apuntar que la desigualdad histórica y estructural de algunos países participantes se reproduce en el terreno de la producción y en la interacción política con las potencias mundiales.
} 
A diferencia de la economía mexicana, que en sus primeros 20 años de reformas neoliberales registró un crecimiento anual variable entre $3.3 \%$ y menos de $2 \%$ anual, la economía china mostró un incremento de $8.8 \%$ durante las tres primeras décadas a partir de sus reformas y apertura comercial (Navarrete, 2010: 49). ${ }^{14}$ Desde 2015 , su crecimiento disminuyó a $7 \%$, mientras que el crecimiento mexicano fue de $2.5 \%$.

Para los intereses de este trabajo vale la pena destacar que con el enorme desarrollo económico del país asiático — hoy es la segunda economía del mundo-, su capacidad de inversión en el extranjero aumentó significativamente. Para 2007, Wu Homgyng reportaba:

5,000 entidades de inversión han establecido casi 10,000 empresas internacionales distribuidas en más de 170 países y regiones del mundo. Los sectores de inversión se concentran en el arrendamiento, el servicio comercial, la explotación mineral, las finanzas, la venta al por mayor y al por menor, que ocupan más de 70 por ciento de las inversiones hacia el exterior [...] (Homgyng, 2010: 18).

En este escenario se ubica la irrupción de los chinos en Simojovel para la compra de ámbar, cuyo costo en el mercado internacional debe ser lo suficientemente redituable como para ofrecer en la zona de extracción precios muy por encima de los que anteriormente allí se pagaban. De acuerdo con la información proporcionada por algunos de estos herméticos compradores asiáticos, los usos de las esferas son diversos, pero principalmente se destinan a la producción de joyería, aunque también sirven para confeccionar rosarios budistas. Basta buscar en internet "joyería china" para encontrar la gran variedad de alhajas confeccionadas con distintos tipos de piedras "naturales" y "preciosas", en las que se incluye el ámbar de Chiapas, pero también del Báltico. Muchas de estas piezas se elaboran con esferas de distintos tamaños, tal y como han sido requeridas en Simojovel (Figuras 5 y 6 ).

De igual forma, quienes trabajan para los asiáticos en la región de estudio narran que, aunque es difícil que los chinos proporcionen información referente a las esferas, alguno comentó que son vendidas en los spas, ${ }^{15}$ tanto en China como en Nueva York, en donde se utilizan para los tratamientos que los clientes solicitan. Las esferas, cuya carga simbólica juega un papel importante en estos procedimientos, por su material, color, transparencia y pureza, se queman durante las sesiones. ${ }^{16}$

${ }^{14}$ Acerca de las diferencias y desigualdades entre las economías china y mexicana, así como de las relaciones comerciales, diplomáticas y culturales entre ambos países existen distintos trabajos, entre éstos los coordinados por Dussel y Trápaga (2010) y Dussel (2016).

${ }^{15}$ Un spa es un establecimiento que ofrece tratamientos de belleza y terapias de relajación.

${ }^{16}$ Aunque alrededor de las esferas de ámbar pudieran existir otros mitos y creencias, el Diccionario de símbolos destaca que la esfera es "[s]ímbolo de la totalidad, como el rotundus alquímico. Corresponde, en el espacio de tres dimensiones, a la circunferencia en el de la línea. Ya para los 


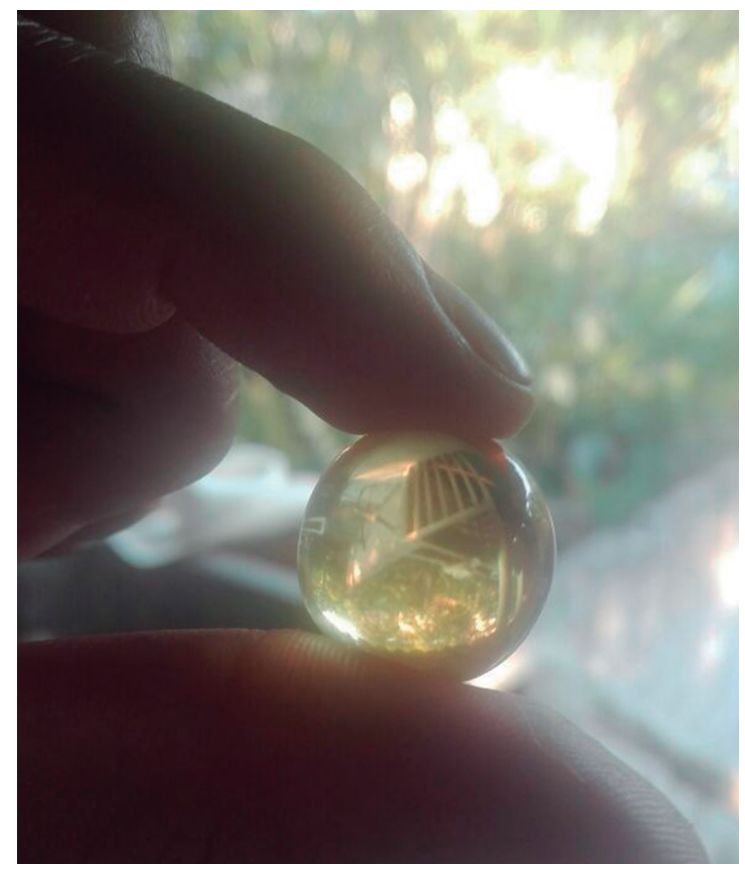

Figura 5. Esfera de ámbar amarillo de primera calidad. Fotografía de Lili García Mayorga.

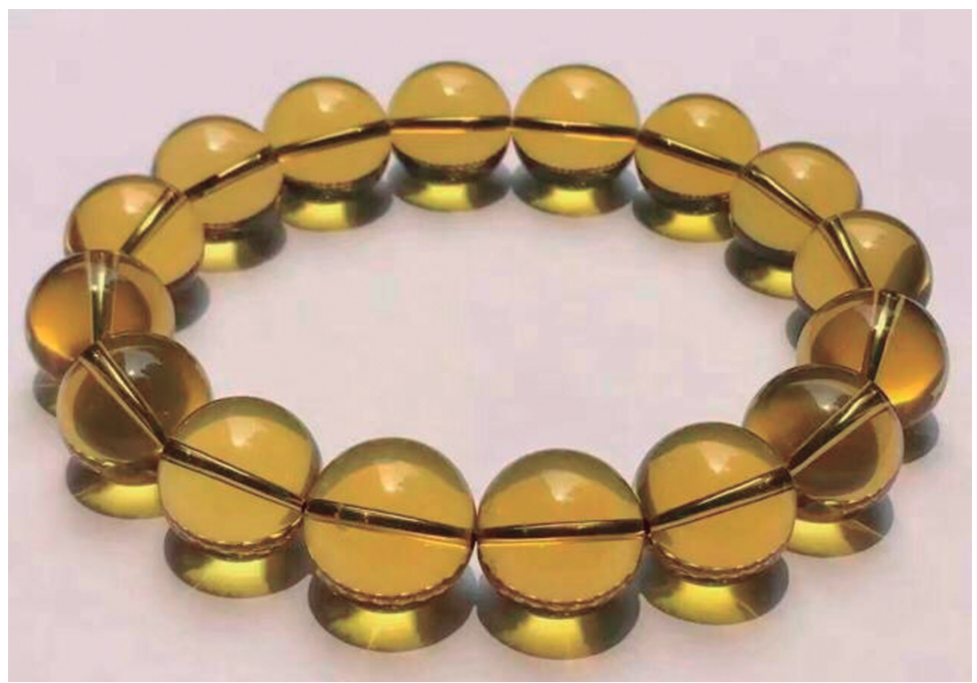

Figura 6. Pulsera de esferas de ámbar. Fotografía de Lili García Mayorga. 
Asimismo, la población local ha creado distintas narrativas acerca de los intereses que los chinos puedan tener por la resina fosilizada: van desde la intención de acaparar el mejor ámbar, para cuando éste se agote en Simojovel lo vendan a los artesanos a precios muy altos, pasando por la construcción de una escultura gigante de Buda, hasta la fabricación de una bomba "más potente que la nuclear", ya que los chinos cuentan con una muy desarrollada tecnología.

Podríamos decir que con sus particularidades y en mucho menor escala, el crecimiento de la minería alrededor del ámbar de Simojovel registrado en las últimas décadas se inscribe en el contexto de lo que Maristella Svampa llama "Consenso de los Commodities", que es la "expansión de megaproyectos tendientes al control, la extracción y exportación de bienes naturales, sin mayor valor agregado". Como plantea la autora, este proceso se ha producido desde los últimos años del siglo xx como parte de los cambios del modelo de acumulación capitalista. Dicho modelo se sustenta en la preeminencia que han adquirido en el mercado internacional materias primas y bienes de consumo demandados de manera creciente por los países centrales y emergentes, y produce "ventajas comparativas visibles en el crecimiento económico y el aumento de las reservas monetarias, al tiempo que produce nuevas asimetrías y profundas desigualdades en las sociedades latinoamericanas" (Svampa, 2013: 31).

Las especificidades en el caso de la minería del ámbar consisten en que se trata de la extracción de un bien natural que, aparte de tener un interés científico, se utiliza en la producción de mercancías de tipo suntuario para un mercado acotado por ciertos gustos, prácticas y creencias, es decir, no tan ampliamente extendidas.

A diferencia de la minería a cielo abierto, la dedicada a extraer la resina fósil se realiza al interior de los cerros y a partir del esfuerzo humano, con el uso de barretas, marros y palas; es decir, no se utiliza maquinaria pesada. Este tipo de explotación no genera los alarmantes problemas socioambientales provocados por la extracción de minerales, ${ }^{17}$ lo que no significa que la perforación de los cerros en donde se encuentra el ámbar no tenga ninguna repercusión ambiental.

presocráticos, esfera equivalía a infinito (lo único uno), e igual a sí mismo, con los atributos de homogeneidad y unicidad. Emblemáticamente, la esfera se identifica con el globo, que, por similitud con los cuerpos celestes, se considera alegoría del mundo. Pero existe aún otro significado de la esfera, más profundo si cabe, Shairos, equivalente a infinito, y en el Banquete, Platón, al referirse al hombre en estado paradisíaco, anterior a la caída, lo juzga andrógino y esférico, por ser la esfera imagen de la totalidad y de la perfección." La esfera terrestre: "El hemisferio norte se considera de la luz, asimilado al principio positivo Yang; y del sur, de las tinieblas o Yin. Por ello los movimientos culturales se producen de norte a sur entre hemisferios. (Cirlot, 2008: 194, 195). En cuanto a los fósiles, recordemos que el ámbar es una resina fosilizada: "Su significado simbólico corresponde en general al de la piedra, pero integra, por su carácter, ideas ambivalentes sobre el tiempo y la eternidad, sobre la vida y la muerte, sobre la evolución de las especies y su petrificación." (Cirlot, 2008: 214).

17 Ver: "Minería a cielo abierto. Irreparable impacto ambiental para el planeta y sus habitantes", $<$ https://www.facebook.com/notes/\%C3\%BAnetealplaneta-jointheplanet/miner\%C3\%ADa-a-cielo-abiertoirreparable-impacto-ambiental-para-el-planeta-y-sus-habi/321391421246853/> . 
Por ejemplo, algunos cerros están a punto de ser atravesados por las excavaciones, lo que provocará enormes derrumbes de montañas. Esto impactaría en el clima, pues estos contenedores naturales de vientos y lluvias desaparecerían. Tal es el caso de un cerro compartido por los ejidos de Lázaro Cárdenas y Monte Cristo, que ha sido explotado por ambos lados. Los habitantes de estos lugares han prohibido que se continúen las excavaciones para evitar el desplome del cerro.

Por otra parte, la sobreexplotación de este recurso en la región de Simojovel ha tenido un impacto social y político importante, y a pesar de que ha habido un saqueo considerable del ámbar de primera, para muchos habitantes de la zona ha representado una oportunidad.

\section{La población local y el aumento de la demanda del ámbar}

Uno de los grupos de la zona que se ha visto beneficiado es el de los ejidatarios propietarios de minas. Este sector no invierte capital ni realiza ningún tipo de esfuerzo y obtiene rentas mensualmente. Un entrevistado expresó lo que muchos mineros y artesanos piensan de este grupo:

Los dueños de las minas son bien ricos por sus rentas que reciben mensualmente, y como no solo una mina tienen, es de varias minas que reciben su paga. [Cada mina tiene más de una cueva y éstas se alquilan a diferentes mineros] Ellos casi ya no trabajan porque tienen sus inquilinos, de 10 a 15 mineros mensualmente, pues ya les sale un buen dinero. Ellos ya no piensan dónde van a conseguir su paga, solo están esperando que les lleguen a dejar sus rentas (Domingo Sánchez, entrevistas, Simojovel de Allende, julio de 2015).

Efectivamente, buena parte de los ejidatarios que cuentan con la ahora preciada resina en sus terrenos renta por mes sus minas, las cuales varían entre $\$ 1,500.00, \$ 2,000.00, \$ 3,000.00$ y hasta $\$ 10,000$, todo depende de la abundancia y la facilidad para extraer el ámbar. Hay sin embargo otros tipos de arreglos: algunos propietarios contratan mineros por $\$ 120.00$ o $\$ 130.00$ pesos diarios y ellos venden las piezas. Otros rentan sus minas a cambio de que quienes las trabajen les entreguen la mitad del ámbar "arrancado", práctica que ha sido muy común en la agricultura.

Para los mineros en general, la llegada de los compradores chinos representó una oportunidad para obtener recursos antes inimaginables (aunque no todos los consiguen). Del conjunto de los que intervienen en la cadena de explotación del ámbar, los mineros habían sido históricamente los menos beneficiados y los más expuestos a sufrir accidentes (derrumbes o inhalación de gases tóxicos), como repiten muchos habitantes de la zona, pero a partir de 2012, varios han logrado ingresos que jamás habían obtenido. No es de extrañar, entonces, el notorio aumento de la población en esta actividad durante los últimos tres años, principal- 
mente entre los jóvenes, la mayoría provenientes de las localidades campesinas de los municipios de la región.

Durante las distintas estancias en la zona entre 2012 y mediados de 2016, preguntando al azar a cualquier joven o muchacha si trabajaba en las minas, en las artesanías o en el comercio del ámbar, la mayoría respondía haber tenido por lo menos alguna experiencia en estas actividades. Por ejemplo, durante el trayecto de la cabecera municipal a un ejido, Juan, un taxista de 26 años de edad, narró que había trabajado en los yacimientos del ejido Chanal Uk'un, Simojovel, desde que tenía 12 años de edad hasta que cumplió 25 , cuando empezó a bajar el precio del ámbar. ${ }^{18}$ Comentó que en ese ejido existen más de 100 minas.

En una ocasión, en el parque central, un joven bolero (lustrador de zapatos) me indicó cómo desde ese punto se podían observar las minas del ejido Los Cocos. Platicó que él había trabajado allí durante un tiempo, pero que después de sufrir un derrumbe que le ocasionó la pérdida de los dedos de un pie y estar inhabilitado durante casi un año, decidió trabajar en el parque central de Simojovel, atendiendo el puesto de bolero que le dejó su padre. ${ }^{19}$

Los varones se incorporan a la minería desde los 12 o 13 años de edad, la mayoría sin conocer el trabajo ni los riesgos a los que se exponen. Muchos realizan sus estudios durante la mañana y trabajan en las minas por las tardes, cuando éstas están cerca de su lugar de residencia. Varios más han abandonado la escuela y otro tanto dejó de emigrar a los Estados Unidos o al norte del país para dedicarse de tiempo completo a la minería.

Por lo regular, coincidieron los mineros con quienes platiqué, aquellos que alquilan una mina lo hacen fuera de su ejido, pues los propietarios prefieren rentar a gente de otras localidades para evitar conflictos con sus vecinos o parientes. Se requiere por lo menos de dos personas para trabajar una mina, ya que mientras uno "raspa y arranca la tierra", el otro, el chalán o ayudante, se hace cargo de juntar y sacar el cascajo. En muchos casos esas dos personas se asocian para pagar la renta.

A los montones de piedra y tierra que son apilados a un costado de las bocas de las minas, llegan mujeres y niños en busca de pequeñas piezas de ámbar para venderlas a precios sumamente bajos con algunos artesanos.

Aquellos mineros que se desplazan a minas lejanas de su localidad, con frecuencia montan campamentos con pedazos de naylón para pasar allí la noche

\footnotetext{
${ }^{18}$ La historia de Juan es sumamente interesante, el trabajo de minero lo interrumpió durante tres años. Cuando tenía 16 años de edad decidió irse "de mojado" a Oklahoma, Estados Unidos. El pollero lo pasó, junto con 22 personas más, de Huitiupán, por el desierto de Sonora. Pagaron el derecho de paso a los narcotraficantes y no tuvieron ningún problema para llegar al lugar que el pollero les consiguió para trabajar y garantizar así el pago de los 15 mil pesos por el viaje. Sólo al terminar de cubrir su deuda podía cambiar de lugar de trabajo. Pero tuvo que regresar a su tierra por la enfermedad de su madre, así volvió a la minería y se casó. Tras la caída del precio del ámbar empezó como taxista (Entrevista, Simojovel, julio de 2015).

${ }^{19}$ Plática informal, julio de 2015.
} 
y sacar el máximo provecho trabajando sin perder tiempo en el traslado a su comunidad. Incluso quienes rentan en un sitio cercano a su lugar de residencia acostumbran acantonarse fuera de la mina cuando han hallado una buena veta de ámbar para evitar así un robo, como les ha sucedido a algunos que han dejado la cueva y al volver al día siguiente el ámbar ya ha sido extraído, sin que los dueños de las minas se hagan responsables.

Por ejemplo, Jesús, ejidatario del ejido Campo La Granja de Simojovel, se desplaza a las minas del ejido Guadalupe Victoria desde hace algunos años. Para llegar a este lugar recorre alrededor de 35 minutos en vehículo y 45 minutos caminando. Viaja dos veces por semana y trabaja dos días, el tiempo que le sea posible, porque asegura que es muy duro aguantar el intenso calor y la incomodidad de las posturas para "raspar la mina". Él, como muchos otros, acostumbra prender una vela y rezar para pedirle permiso al cerro y no tener percances. ${ }^{20}$ Lleva consigo un plástico, tostadas y agua para acampar. Según comenta, allí hay alrededor de 250 mineros trabajando, que llegan de diferentes ejidos de la región. "Como dormimos por grupos, se ven muchos nayleros", "se forman como 100 campamentos". Jesús contrata a un ayudante, que es el que se encarga de sacar la tierra, mientras él excava en la cueva. Le paga $\$ 120.00$ el jornal.

El problema que enfrenta, al igual que los demás mineros, es que tres días antes de terminar el contrato del alquiler tiene que pagar la renta del siguiente mes, de lo contrario el propietario lo rentará a quien pague con anticipación. Los propietarios de las minas tienen listas de espera para rentar. Jesús, como muchos otros adultos con tierra, siembra milpa para el consumo familiar, pero desde que inició el trabajo como minero, buena parte de los ingresos provienen de la venta del ámbar con los coyotes o los artesanos de la cabecera de Simojovel. Además, su esposa ya empezó a tallar la gema y hacer collares y pulseras (Entrevista, ejido Campo La Granja, Simojovel, 28 de noviembre de 2013).

¿Existen mujeres mineras? Al formular esta pregunta entre la población local de ambos sexos no faltaron las risas y miradas de extrañeza hacia mí. El trabajo en las minas requiere "fuerza y resistencia", es una actividad que, de acuerdo con las nociones más ampliamente aceptadas y naturalizadas acerca de las características de los géneros, sólo pueden realizar los varones. Las mujeres generalmente se dedican a la talla y comercialización de artesanías de esta resina, aunque aquí también participan varones. Al igual que en la agricultura, algunos niños, desde los ocho años de edad, acompañan a sus padres o hermanos mayores a las minas y ayudan a sacar el cascajo; otros, varones y mujeres, a esa edad se inician con el tallado de pequeñas piezas hasta conocer los distintos pasos para confeccionar

\footnotetext{
${ }^{20}$ Algunas mujeres comentaron que aunque se prenda vela y se rece no todos los cerros dan ámbar: "el dueño del cerro de Pauchil, Huitiupán, es muy codo: si empiezan a sacar la tierra tira piedras y puede aplastar, pero hay dueños muy buenos y dan bastante ámbar". Para la población de origen mesoamericano en general, los cerros y las cuevas están habitados por seres sobrenaturales. Cada cerro tiene un dueño y éste es responsable de las lluvias, las cosechas y los animales (Guiteras, 1966; Köhler, 2007).
} 
aquellas que les solicitan los artesanos para la elaboración de aretes, pulseras, collares, rosarios, etc. ${ }^{21}$

El modo de operar de los compradores chinos consiste en ofrecer un precio preferencial a hombres jóvenes, generalmente hablantes de tzotzil, que se encargan de adquirir las mejores piezas. Para que sepan distinguir las distintas calidades de la gema han sido capacitados por los compradores asiáticos. Estos "coyotes" o intermediarios esperan diariamente la salida de los mineros con el ámbar recién extraído; llevan consigo grandes cantidades de dinero que los chinos les proporcionan, así como una pequeña báscula, lupa y mochila en la que portan el dinero y después el ámbar adquirido. Las herramientas para la minería y para examinar la calidad de la gema las adquieren principalmente en la tienda que montó uno de los compradores de origen norteamericano, pero que trabaja para el mercado chino.

Los nutridos grupos de intermediarios que se reúnen en espera de los mineros que salen de las minas, regularmente a las tres de la tarde, han generado conflictos con la población de las comunidades en donde concurren a comprar el ámbar, ya sea por las quejas de las mujeres ante el acoso que sufren de parte de estos hombres cuando transitan por donde ellos se reúnen, por los asaltos, las balaceras y el tráfico de drogas y armas que han ocurrido cuando se forman estos grupos. ${ }^{22}$ Ante tales sucesos, en la entrada de muchos de los barrios de la cabecera municipal de Simojovel y de las localidades en donde se extrae ámbar lo primero que se observa es un letrero sobre una lámina que prohíbe a los extraños reunirse y estacionarse en esos lugares. ${ }^{23}$

Los compradores chinos tienen sus lugares de operación en los dos pequeños hoteles del centro de Simojovel. Allí reciben a los jóvenes intermediarios que trabajan para ellos, a los mineros y talladores que llegan por su cuenta a ofrecerles el ámbar en bruto o en esferas. De acuerdo con varios entrevistados, acostumbran tener allí grandes cantidades de dinero, algunos llevan consigo "tres o cuatro millones de pesos en efectivo". Por tal razón contratan guardaespaldas, pues algunos han sufrido asaltos en los que han sido despojados de fuertes sumas de dinero y piezas de ámbar, además de resultar heridos.

\footnotetext{
${ }^{21}$ Los barrios de la cabecera municipal en donde se ha formado un gran número de talleres familiares de talladores son El Cielito I, El Cielito II, Nueva Primavera, San Caralampio, Nuevo Urbano, Poyholó, Sharpes, Guadalupe, además del grupo del Mercado y el grupo del Bazar Choj Choj. Por otra parte, una descripción minuciosa de cada una de las actividades realizadas en la minería y en la producción artesanal se encuentra en Ytuarte, 2014.

${ }^{22}$ La población local en general hace referencia al notable incremento de la violencia que en los últimos años se vive en la región. Muchos lo atribuyen a la afluencia de una gran cantidad de gente que llega de distintas partes de la zona y de otros países, no sólo para trabajar en las minas y alrededor del ámbar, sino para traficar con armas, drogas y personas.

${ }^{23}$ Ésta es una vieja práctica de la población de la zona. Desde los años ochenta, durante los intensos enfrentamientos por las disputas agrarias, las localidades participantes en el movimiento agrario colocaban este tipo de letreros. En ese tiempo prohibían la entrada de "extraños", de "cochiteros" (comerciantes de puercos), de "destacamentos de la policía y del ejército mexicano".
} 
Por su parte, los compradores locales que solían fijar precios y acaparar el ámbar han denunciado en los medios de comunicación la sobreexplotación de este recurso y el saqueo sin control que los chinos están llevando a cabo de las mejores piezas de la zona. No obstante, algunos más forman parte de los abastecedores del mercado internacional, principalmente asiático (Figura 7).

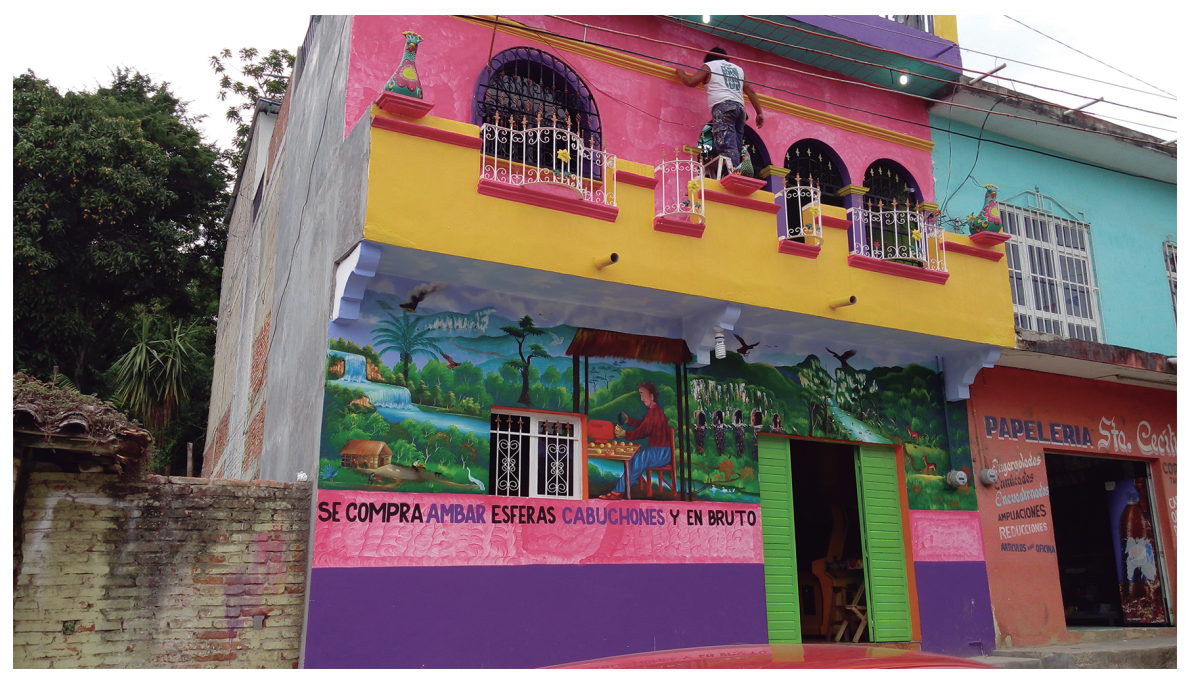

Figura 7. Tienda de compra de ámbar en Simojovel, Chiapas.

Fotografía de Sonia Toledo Tello.

Los artesanos también se han visto afectados por los altos costos de su principal materia prima, así como por el hecho de sólo poder adquirir ámbar de segunda, ya que el de primera se va casi todo al extranjero y es inaccesible por sus altos costos. Lo que sigue es parte de una nota periodística publicada en 2015:

A mediados del 2012, los precios de la gema de Chiapas se disparan, situación que hoy persiste, con ello trae un sin número de conflictos internos entre mineros, artesanos del ámbar y coyotes, ahora con un nuevo actor en el comercio de esta gema: los chinos. Los artesanos cuestionan que el mejor producto está siendo exportado mayormente a China, Hong Kong y Estados Unidos, y enviado por empresas de paquetería a nivel mundial. [...] "sin que el gobierno ponga un orden al saqueo de la gema representativa de Simojovel y del estado de Chiapas". Otras fuentes consultadas confirmaron que el producto viaja sin problemas y que en las aduanas mexicanas pasa sin ningún control, a la vez confirmaron que un promedio de 100 kilos mensuales está saliendo del estado, sin que alguna autoridad ponga freno a este tema, donde el único fin es que las esferas calibradas se conviertan en rosarios budistas (Gómez, 2013: 9).

De acuerdo con la información proporcionada por una persona que trabajó muy de cerca con los chinos, el ámbar lo envían de Simojovel a Tuxtla, donde es 
recibido por personas que también trabajan con los compradores asiáticos. De allí lo mandan a la Ciudad de México o a Colima para transportarlo en avión o en barco a China y Estados Unidos.

Por otra parte, en los últimos cuatro años también se ha incrementado el número de puestos de ámbar (Figura 8). El parque central de Simojovel es ocupado por artesanos que diariamente colocan sus puestos. Son grupos constituidos por tres y hasta ocho socios, afiliados a Artesanos del Ámbar A.C. o al Consejo Regulador del Ámbar de Chiapas, éste último ligado a la Casa de las Artesanías del Gobierno del Estado chiapaneco. Cada agrupación cuenta con más de 40 grupos de artesanos originarios de los ejidos del municipio y de la misma cabecera. $^{24}$

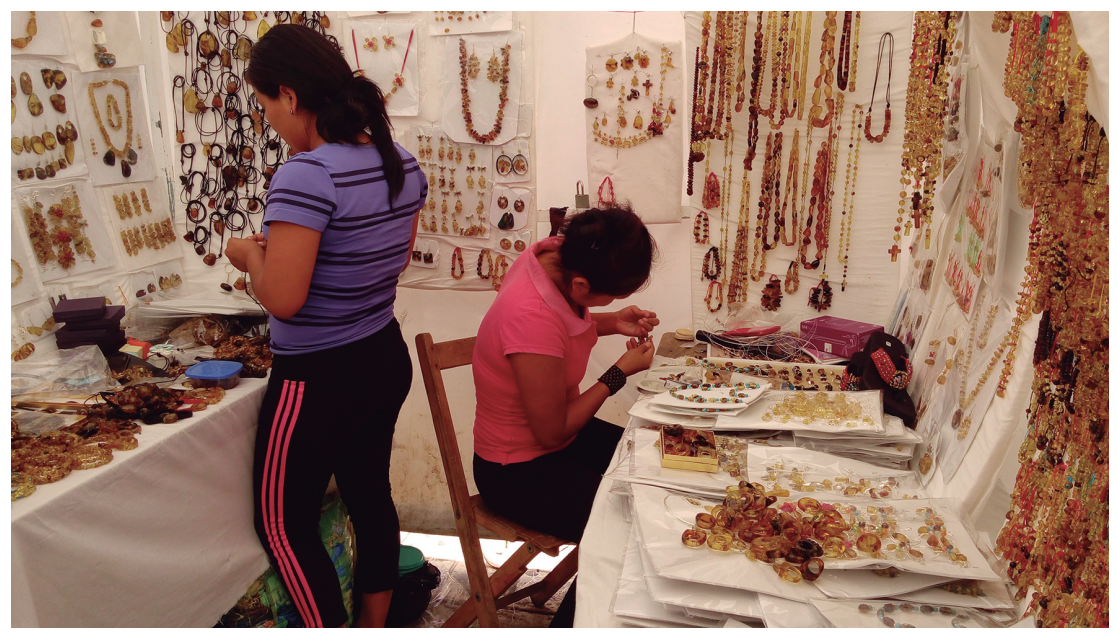

Figura 8. Puesto de venta de ámbar. Fotografía de Sonia Toledo Tello.

Los artesanos con mayor experiencia lamentan que a raíz de la presencia de los chinos se esté sobreexplotando el ámbar y que la cada vez mayor competencia entre los de su gremio abarate las piezas que se venden localmente. Esta queja proviene de quienes conforman este sector en Simojovel y de los que desde hace varios años tienen puestos en la plaza de Santo Domingo de San Cristóbal de Las Casas. ${ }^{25}$

${ }^{24}$ Los artesanos afiliados a estas agrupaciones participan en la Feria del Ámbar o Expo Ámbar, que desde 1998 se organiza en San Cristóbal de Las Casas durante el mes de agosto, por parte del Instituto Casa de las Artesanías de Chiapas, la Secretaría de Desarrollo Social (Sedesol), El Fondo Nacional para el Fomento de las Artesanías (Fonart) y el Ayuntamiento de San Cristóbal de Las Casas. Éste es un foro importante para los artesanos, pero no está exento de conflictos e inconformidades por el manejo de espacios, la premiación de las mejores piezas en distintas categorías, etcétera.

${ }^{25} \mathrm{~A}$ diferencia de hace algunos años, hoy en día encontramos pequeños puestos dedicados a la venta de la gema en diferentes plazas de ciudades y pueblos, así como sobre las carreteras, en las orillas de poblados en donde no había una tradición de "ambareros". 
La disponibilidad de dinero por parte de muchos pobladores debido al auge del ámbar ha estimulado la proliferación de centros de consumo de alcohol y drogas, así como el aumento de la prostitución y el tráfico de armas, hecho que no es exclusivo de esta zona. Todo ello tolerado por las autoridades de distintos niveles, cuando no promovido por algunas. ${ }^{26}$ Esto ha generado protestas y movilizaciones de una parte importante de la población de la región, del llamado "Pueblo Creyente”, encabezada por el párroco católico de Simojovel, Marcelo Pérez Pérez. ${ }^{27}$

La fiebre del ámbar empezó a bajar a mediados de 2015. Algunos de los comerciantes locales que trabajaban con los asiáticos afirman que el mercado para esta gema ya está saturado, por ello el precio ha caído y varios extranjeros se están retirando de Simojovel. A principios de 2016, los coyotes de origen norteamericano que trabajaban para los chinos abandonaron uno de los hoteles que rentaron durante tres años para residir en la cabecera municipal. Cerraron la tienda que allí instalaron y que era el principal centro abastecedor de herramientas para mineros e intermediarios. Todavía a mediados de 2016 se encontraban tres comerciantes chinos en Simojovel, pero si en años anteriores llegaron a pagar \$280.00 el gramo de ámbar de primera, en ese momento ofrecían $\$ 80.00$ o $\$ 100.00$ cuando mucho. Aun así, fue posible apreciar que los vendedores de la gema no dejaban de llegar en busca de los compradores asiáticos a lo largo del día.

\section{Jóvenes mineros, artesanos y comerciantes de localidades campesinas}

Un poco antes del apogeo del ámbar (finales de 2011), las autoridades locales y padres de familia señalaban que una parte importante de la población infantil de ambos sexos cursaba la primaria; varios jóvenes, de entre 13 y 18 años, estudiaban la secundaria y el bachillerato y, los menos, alguna carrera técnica o universitaria en la cabecera municipal e incluso en la capital del estado o en San Cristóbal de Las Casas. ${ }^{28}$

${ }^{26}$ Elio Henríquez, corresponsal del diario La Jornada, dio a conocer en 2015 la detención del ex alcalde priista Juan Gómez Domínguez, junto con dos personas más, acusados de portar armas de alto calibre y drogas, así como de hostigamiento al párroco de Simojovel. Añade que el hermano del ex alcalde detenido, Ramiro, quien también fue presidente municipal, igualmente tiene orden de aprehensión por distintos delitos, pero logró escapar (La Jornada en línea, 17 de junio de 2015).

${ }^{27}$ Del 23 al 27 marzo de 2015, 15 mil integrantes del Pueblo Creyente caminaron de Simojovel a Tuxtla Gutiérrez, exigiendo el cierre de cantinas y el alto a los asesinatos, la prostitución y el tráfico de drogas y armas <https://sipaz.wordpress.com/2015/03/27/chiapas-finaliza-en-tuxtla-gutierrez-peregrinacion-del-pueblo-creyente-despues-de-4-dias-de-recorrido/>. El 18 de julio de 2016 nuevamente se movilizó este grupo, con aproximadamente 20 mil participantes, en apoyo al movimiento magisterial de la Coordinadora Nacional de Trabajadores de la Educación y en demanda del cese a la narcoviolencia en la región de Simojovel y el estado, <http:/www.jornada.unam.mx/ultimas/2016/07/18/ catolicos-peregrinan-en-apoyo-a-movimiento-maestros-en-chiapa $>$.

${ }^{28}$ Estos comentarios los recibí durante las entrevistas realizadas para un trabajo anterior. Cabe mencionar que tal fenómeno resulta muy significativo en esta región porque hasta hace pocos años parte de las localidades campesinas carecía de acceso a la educación y a otros servicios. Esto se debía 
Los adultos comentaban que sus hijos se involucraban cada vez menos en los trabajos agrícolas. Asimismo, expresaban su disgusto ante "la falta de respeto" mostrada por varios de los jóvenes, así como por los vicios que, aseguraban, estos iban adquiriendo. Para los adultos, las formas de vestir, el consumo de alcohol y drogas, el vandalismo y los casamientos sin el consentimiento de los padres o las huidas representan las faltas de respeto más frecuentes de los jóvenes hacia la autoridad paterna.

A partir del auge del ámbar, estas expresiones y comportamientos se han extendido y acentuado, principalmente entre aquellos que residen en la cabecera municipal o en las localidades adyacentes. En este sentido, las personas adultas y el sacerdote de Simojovel expresan que los jóvenes ahora obtienen el dinero "fácil" y de la misma manera lo gastan, los varones sobre todo en cantinas, drogas y armas.

Ciertamente, en los últimos años se observan cambios importantes en el tipo de consumo de los jóvenes, quienes al parecer tratan de distanciarse cada vez más de las formas de vida de sus padres y abuelos campesinos. Los varones, a diferencia de sus ascendientes que aspiraban a tener tierra, ganado y un buen caballo, anhelan comprar una camioneta, generalmente tipo pickup de ocho cilindros; es decir, grande y poderosa, aunque algunos se conforman con una buena motocicleta. Aquellos que han corrido con "la suerte" de encontrar piezas de ámbar de calidad o que son empleados de los chinos gastan su dinero en la construcción o mejora de su casa, en ropa y calzado tipo banda ranchera, teléfonos celulares, tabletas y aparatos electrodomésticos, lo cual representa ahora un buen atractivo para las muchachas. Las mujeres jóvenes que se dedican a la elaboración y venta de artesanías de ámbar también contribuyen a la mejora de sus viviendas y, al igual que los varones, adquieren televisores y aparatos de sonido, hornos de microondas, además de faldas y pantalones de mezclilla a la moda, ${ }^{29}$ maquillaje y tintes para el cabello. También es cierto que algunos jóvenes, de ambos sexos, han aprovechado lo que ganan para financiar sus estudios y hay quienes han invertido en la compra de tierras.

Con el paulatino retiro de los compradores chinos y de sus operadores, así como la caída de los precios del ámbar, varios de los entrevistados expresaron su temor ante el probable aumento de robos y asaltos, pues afirman que "muchos ya se acostumbraron a manejar bastante dinero".

a que varias de ellas se fundaron en la segunda mitad de los ochenta, sobre los predios de las fincas, y no tenían regularizadas las tierras (no estaban reconocidas como ejidos). Y aquellas que contaban con escuelas dejaron de enviar a niños y jóvenes al sumarse al movimiento zapatista, a partir de 1994, y estar en resistencia. En 2002, durante la gubernatura de Pablo Salazar Mendiguchía, muchos de los campesinos prozapatistas aceptaron los servicios gubernamentales a cambio de obtener la regularización agraria. Para abundar más sobre este complejo proceso ver Toledo, 2012: Capítulo V.

${ }^{29}$ En los últimos años, ha aumentado notablemente la cantidad de tiendas de ropa, fundamentalmente de mezclilla, y cosméticos, así como las zapaterías que ofrecen mercancías elaboradas en las maquiladoras del centro del país. 


\section{Consideraciones finales}

La explotación del ámbar adquirió importancia desde finales del siglo xx y sobre todo en los últimos cuatro años, al conjuntarse varios procesos: la desaparición de las fincas y la crisis de la economía campesina como resultado de las políticas neoliberales impulsadas por el Estado mexicano, en conjunto con la fama que adquirió el ámbar a partir de la difusión masiva en el cine y la literatura de los descubrimientos científicos sobre la preservación del ADN en los fósiles, así como las reformas y apertura de la economía de la República Popular China al mercado global, que permitieron la llegada de algunos grupos en busca de esta gema cargada de símbolos y misticismo, para colocarla en ciertos nichos de los mercados estadounidense y chino, principalmente, a través de la joyería, los rosarios budistas y los spas más modernos y lujosos.

La convergencia de estos procesos con la enorme disposición de ámbar en la región norte de Chiapas, donde se ubica Simojovel, convirtieron de nuevo al municipio en un lugar de atracción laboral. Si durante cien años aproximadamente, de fines del siglo xIx a fines del xx, las fincas agroexportadoras atrajeron abundante mano de obra regional, en los últimos años, gracias a las minas, el lugar nuevamente adquirió el papel de importante receptor de población, en especial de jóvenes de familias campesinas empobrecidas en busca de alternativas económicas. Ello generó expectativas económicas, creó oportunidades para muchos y contribuyó a la disminución, por lo menos temporal, de la migración al norte del país y los Estados Unidos.

Con los elevados precios que ofrecían, los compradores chinos provocaron la apertura de un gran número de minas en distintas localidades del municipio de Simojovel y de varias más de la región. En tan sólo cuatro años extrajeron el ámbar de mejor calidad y causaron serios daños en el espacio físico al incitar la perforación de varios cerros.

Las formas de operar de los compradores chinos corresponden a los mecanismos y prácticas de la fase actual del capitalismo desterritorializado, voraz y agresivo. Sin establecer relaciones laborales ni asumir responsabilidad ambiental y social alguna, los asiáticos obtuvieron el máximo provecho durante el tiempo que les resultó conveniente. Disputaron el control del ámbar a los comerciantes locales que antes lo acumulaban, incluso algunos de éstos se convirtieron en parte de los abastecedores del comercio chino. Los habitantes de la región, "libremente", sin mejores alternativas económicas, se han organizado para establecer alguno de los arreglos descritos en el texto y explotar las minas. El trabajo lo han venido realizando bajo su propio riesgo, sin contar con seguridad o servicios de salud, pues el patrón es invisible. Quienes han participado en las actividades relacionadas con la explotación del ámbar se encuentran del todo a merced del mercado, específicamente de un nicho limitado.

En la configuración del lugar como "tierra del ámbar" han intervenido las acciones de los comerciantes regionales, nacionales y extranjeros y de las auto- 
ridades de dependencias federales (Fonart), estatales y municipales, así como las relaciones que han entablado los pobladores involucrados en las distintas acciones relacionadas con la explotación del recurso mineral. No obstante, a pesar de la crisis en la que se encuentra, la agricultura sigue siendo una de las actividades importantes en la reproducción de buena parte de las familias de la zona.

Por otro lado, el acceso que una parte considerable de los jóvenes de la zona ha tenido a la educación, a nuevas ideas, imágenes y modas (musicales, del vestir, de poses y gestos) a través de internet, la televisión y las redes sociales, ha contribuido a crear nuevas expectativas de vida, modelos de ser joven y diversas formas de consumo. Estas aspiraciones fueron alentadas por la, al parecer, efímera bonanza económica que en los últimos cuatro años generaron los compradores extranjeros de ámbar, principalmente los asiáticos.

El consumo de imágenes, ideas y mercancías diversas (incluidas drogas y armas), dirigidas al cambio de imagen de jóvenes campesinos a jóvenes "modernos" y poderosos, produce tensiones y conflictos con sus padres y abuelos - muchos de estos monolinguies-, apenas liberados del patrón de la finca en la década de 1980 .

El descenso de la demanda del ámbar desde mediados de 2015 y la consecuente baja de los precios abre nuevamente la puerta para colocar, sobre todo a los jóvenes, en condiciones totalmente desventajosas. La mayoría sin posibilidades de concluir una carrera técnica o profesional, desempleados o con salarios muy bajos y expectativas insatisfechas. En este escenario, la migración y el crimen organizado representan para algunos las vías para alcanzar sus aspiraciones.

\section{Bibliografía}

Anguiano Roch, Eugenio

2010 "Perspectivas a largo plazo de la relación sino-mexicana", Hacia un diálogo entre México y China. Dos y tres décadas de cambios socioeconómicos, pp. 429443, Enrique Dussel y Yolanda Trápaga (coords.). México: Senado de la República, LXI Legislatura (Comisión de Relaciones Exteriores, Asia Pacífico), China Institutes of Contemporary International Relations, Fundación Friedrich Ebert, Universidad Nacional Autónoma de México, Centro de Estudios China-México, Facultad de Economía.

Bachelard, Gastón

1988 La formación del espíritu científico. Contribución al psicoanálisis del conocimiento

[1938] objetivo. México: Siglo XXI.

Bartra, Roger

1979 Estructura agraria y clases sociales en México. México: Era, Universidad Nacional Autónoma de México. 
Blog SIPAZ

2015 "Peregrinación del pueblo creyente", <https://sipaz.wordpress.com/2015/03/27/ chiapas-finaliza-en-tuxtla-gutierrez-peregrinacion-del-pueblo-creyentedespues-de-4-dias-de-recorrido/> [Consultada el 28 de marzo de 2015].

Blom, Frans

2004 "Nota histórica relacionada con el comercio del ámbar precolombino", Ámbar de Chiapas. Historia, ciencia y estética, pp. 68-76, Lee Whiting, Thomas A. (coord.). México: Gobierno del Estado de Chiapas.

Bourdieu, Pierre y Loïc J. D. Wacquant

1995 Respuestas por una antropología reflexiva. México: Grijalbo.

IX Censo General de Población

1971 Estado de Chiapas, 1970. México: Secretaría de Industria y Comercio.

Cirlot, Juan Eduardo

2008 Diccionario de símbolos. Barcelona: Siruela.

[1997]

Dussel Peters, Enrique (coord.).

2016 La relación México-China. Desempeño y propuestas para 2016-2018. México: Unión de Universidades de América Latina y el Caribe, Cámara de Comercio de México en China, Universidad Nacional Autónoma de México, Centro de Estudios China-México, Facultad de Economía, <http://www.dusselpeters. com/101.pdf $>$ [Consultada el 26 de octubre de 2015].

Dussel Peters, Enrique y Yolanda Trápaga Delfín (coords.)

2010 Hacia un diálogo entre México y China. Dos y tres décadas de cambios socioeconómicos. México: Senado de la República, LXI Legislatura (Comisión de Relaciones Exteriores, Asia Pacífico), China Institutes of Contemporary International Relations, Fundación Friedrich Ebert, Universidad Nacional Autónoma de México, Centro de Estudios China-México, Facultad de Economía.

Escobar, Arturo

2010 Territorios de diferencia: lugar, movimientos, vida, redes. Colombia: Envión [2008] Editores.

Facebook

2012

"Minería a cielo abierto. Irreparable impacto ambiental para el planeta y sus habitantes", <https:/www.facebook.com/notes/\%C3\%BAnetealplanetajointheplanet/miner\%C3\%ADa-a-cielo-abierto-irreparable-impacto-ambientalpara-el-planeta-y-sus-habi/321391421246853/> [Consultada el 5 de agosto de 2016].

Gómez, Bela

2013 "Las esferas de ámbar, Nueva disputa del comercio chino en Simojovel”, Diario Mirada Sur. San Cristóbal de las Casas, Chiapas, 21 de febrero, III 
(178): 9, <https://issuu.com/miradasur/docs/mirada_sur_178> [Consultada el $1^{\circ}$ de mayo de 2015].

Guiteras Holmes, Calixta

1996 Los peligros del alma. Visión del mundo de un tzotzil. México: Fondo de Cultura Económica.

Harvey, David

1998 La condición de la posmodernidad. Investigación sobre los orígenes del cambio cultural. Buenos Aires: Amorrortu Editores.

2005 Breve historia del neoliberalismo. España: Ediciones Akal, S.A.

2007 Espacios de esperanza. España: Ediciones Akal, S.A.

[2000]

Harvey, Neil

2000 La rebelión de Chiapas. La lucha por la tierra y la democracia. México: Ediciones Era.

Henríquez, Elio

2016 "Católicos peregrinan en apoyo a movimiento de maestros en Chiapas", $<$ http://www.jornada.unam.mx/ultimas/2016/07/18/catolicos-peregrinan-enapoyo-a-movimiento-maestros-en-chiapas $>$ [Consultada el 19 de julio de 2016].

Homgyng, Wu

2010 "Treinta años de relaciones de China y México como socios estratégicos: desarrollo económico y social”, Hacia un diálogo entre México y China. Dos y tres décadas de cambios socioeconómicos, pp. 9-37. Enrique Dussel y Yolanda Trápaga (coords.). México: Senado de la República, LXI Legislatura (Comisión de Relaciones Exteriores, Asia Pacífico), China Institutes of Contemporary International Relations, Fundación Friedrich Ebert, Universidad Nacional Autónoma de México, Centro de Estudios China-México, Facultad de Economía.

Instituto Nacional de Estadística y Geografía

s/f Mapa Digital de México para Escritorio, <http:/www.inegi.org.mx/geo/contenidos/mapadigital/> [Consultada el 20 de febrero de 2017].

Köhler, Ulrich

2007 "Los dioses de los cerros entre los tzotziles en su contexto interétnico", Estudios de Cultura Maya, XXX: 139-152. DOI: http://dx.doi.org/10.19130/iifl. ecm.2007.30.625

Lee Whiting, Thomas A. (coord.)

2004 Ámbar de Chiapas. Historia, ciencia y estética. México: Gobierno del Estado de Chiapas.

Lowe, Lynneth S.

2005 El ámbar de Chiapas y su distribución en Mesoamérica. México: Universidad Na- 
cional Autónoma de México, Instituto de Investigaciones Filológicas, Centro de Estudios Mayas.

Maidana, Andrea Carolina, María Adelaida Colangelo y Liliana Tamagno

2013 "Ser indígena y ser joven. Entre la etnicidad y la clase", Desacatos, 42: 131144.

Margulis, Mario y Marcelo Urresti

s/f "La construcción social de la condición de juventud", <http://www2.perio. unlp.edu.ar/catedras/system/files/mario_margulis_y_marcelo_urresti_la_ construccion_social_de_la_condicion_de_juventud_urresti.pdf $>$ [Consultada el 25 de octubre de $\overline{20} \overline{15}$ ].

Morales Troncosa, Carlos

2010 "La relación comercial México-China durante los últimos 25 años", Hacia un diálogo entre México y China. Dos y tres décadas de cambios socioeconómicos, pp. 339-355. Enrique Dussel y Yolanda Trápaga (coords.). México: Senado de la República, LXI Legislatura (Comisión de Relaciones Exteriores, Asia Pacífico), China Institutes of Contemporary International Relations, Fundación Friedrich Ebert, Universidad Nacional Autónoma de México, Centro de Estudios China-México, Facultad de Economía.

Municipio de Simojovel

s/f Sistema Estatal y Municipal de Base de datos (SIMBAD), <http://sc.inegi.org. $\mathrm{mx} /$ cobdem/consulta-por-ageo.jsp $>$.

Navarrete Cáceres, Carlos y Thomas A. Lee Whiting

2004 "Apuntes sobre el trabajo de Simojovel en 1968", Ámbar de Chiapas. Historia, ciencia y estética, pp. 78-87. Thomas A. Lee Whiting (ed.). México: Gobierno del Estado de Chiapas.

Navarrete, Jorge Eduardo

2010 "La evolución de China y México tras la reforma y la apertura. Una visión comparativa”, Hacia un diálogo entre México y China. Dos y tres décadas de cambios socioeconómicos, pp. 45-62, Enrique Dussel y Yolanda Trápaga (coords.). México: Senado de la República, LXI Legislatura (Comisión de Relaciones Exteriores, Asia Pacífico), China Institutes of Contemporary International Relations, Fundación Friedrich Ebert, Universidad Nacional Autónoma de México, Centro de Estudios China-México, Facultad de Economía.

Peña, Moisés T. de la

1951 Chiapas Económico. Tuxtla Gutiérrez: Departamento de Prensa y Turismo (Sección Autográfica), 4 vols.

Pérez Castro, Ana Bella

1989 Entre montañas y cafetales. México: Universidad Nacional Autónoma de México, Instituto de Investigaciones Antropológicas. 
Robinson, William I.

2015 América Latina y el capitalismo global. Una perspectiva crítica de la globalización.

[2008] México: Siglo XXI Editores.

Salazar Peralta, Ana María

1988 La participación estatal en la producción y comercialización del café en la región norte del estado de Chiapas. México: Universidad Nacional Autónoma de México, Instituto de Investigaciones Antropológicas.

Santos, Milton

$2000 \quad$ La naturaleza del espacio. Barcelona: Editorial Ariel.

Svampa, Maristella

2013 "Consenso de los Commodities" y lenguajes de valoración en América Latina", Nueva Sociedad, 244: 30-46, < http://nuso.org/media/articles/downloads/3926_1.pdf> [Consultada el 2 de agosto de 2016].

Toledo Tello, Sonia

2002 Fincas, poder y cultura en Simojovel, Chiapas. México: Universidad Nacional Autónoma de México, Programa de Investigaciones Multidisciplinarias sobre Mesoamérica y el Sureste, Universidad Autónoma de Chiapas, Instituto de Estudios Indígenas.

2012 "De las fincas a las comunidades agrarias. La construcción de los espacios sociales en Simojovel y Huitiupán, Chiapas (s. XIX-S. XXI)", tesis de Doctorado en Estudios Mesoamericanos. México: Universidad Nacional Autónoma de México, Facultad de Filosofía y Letras, Instituto de Investigaciones Filológicas.

Viqueira, Juan Pedro

1997 Indios rebeldes e idólatras. Dos ensayos históricos sobre la rebelión india de Cancuc, Chiapas, acaecida en el año de 1712. México: Centro de Investigaciones y Estudios Superiores en Antropología Social.

Wolf, Eric y Sydney W. Mintz

1975 "Haciendas y plantaciones en Mesoamérica y Las Antillas", Haciendas, latifundios y plantaciones en América Latina, pp. 493-531, Enrique Florescano (coord.). México: Siglo XXI.

Ytuarte-Núñez, Claudia

2014 Cultura y comunicación en el intercambio global de mercancías: el ámbar de Chiapas, México. México: Universidad Autónoma de Chiapas, Universidad Autónoma Metropolitana-Iztapalapa. 